Western University Scholarship@Western

$1-5-2016$

\title{
Oxygen-isotope Variations in Post-glacial Lake Ontario
}

Ryan Hladyniuk

The University of Western Ontario, r.hladyniuk@austin.utexas.edu

Fred J. Longstaffe

The University of Western Ontario, flongsta@uwo.ca

Follow this and additional works at: https://ir.lib.uwo.ca/earthpub

Part of the Earth Sciences Commons

Citation of this paper:

Hladyniuk, Ryan and Longstaffe, Fred J., "Oxygen-isotope Variations in Post-glacial Lake Ontario" (2016). Earth Sciences Publications. 4.

https://ir.lib.uwo.ca/earthpub/4 
1 Oxygen-isotope variations in post-glacial Lake Ontario

2

3 Ryan Hladyniuk $^{1}$ and Fred J. Longstaffe ${ }^{1}$

4

$5{ }^{1}$ Department of Earth Sciences, The University of Western Ontario, London, Ontario,

6 Canada N6A5B7

7

8 Corresponding authors, rhladyn@uwo.ca 1-519-619-3857; flongsta@uwo.ca, 1-519-661$9 \quad 3177$

10

11 Keywords: Lake Ontario, oxygen isotopes, glacial meltwater, Laurentide Ice Sheet, late-

12 Quaternary climate change

13

14

15

16

17

18

19

20

21

22 
23 Abstract

24 The role of glacial meltwater input to the Atlantic Ocean in triggering the Younger Dryas

25 (YD) cooling event has been the subject of controversy in recent literature. Lake Ontario

26 is ideally situated to test for possible meltwater passage from upstream glacial lakes and

27 the Laurentide Ice Sheet (LIS) to the Atlantic Ocean via the lower Great Lakes. Here, we

28 use the oxygen-isotope compositions of ostracode valves and clam shells from three Lake

29 Ontario sediment cores to identify glacial meltwater contributions to ancient Lake

30 Ontario since the retreat of the LIS $\left(\sim 16,500\right.$ cal $\left.\left[13,300{ }^{14} \mathrm{C}\right] \mathrm{BP}\right)$. Differences in

31 mineralogy and sediment grain size are also used to identify changes in the hydrologic

32 regime. The average lakewater $\delta^{18} \mathrm{O}$ of $-17.5 \%$ (determined from ostracode

33 compositions) indicates a significant contribution from glacial meltwater. Upon LIS

34 retreat from the St. Lawrence lowlands, ancient Lake Ontario (glacial Lake Iroquois)

35 lakewater $\delta^{18} \mathrm{O}$ increased to $-12 \%$ largely because of the loss of low- ${ }^{18} \mathrm{O}$ glacial

36 meltwater input. A subsequent decrease in lakewater $\delta^{18} \mathrm{O}$ (from -12 to $-14 \%$ ),

37 accompanied by a median sediment grain size increase to $9 \mu \mathrm{m}$, indicates that ancient

38 Lake Ontario received a final pulse of meltwater $(\sim 13,000-12,500$ cal $[11,100-10,500$

$\left.39{ }^{14} \mathrm{C}\right] \mathrm{BP}$ ) before the onset of hydrologic closure. This meltwater pulse, which is also

40 recorded in a previously reported brief freshening of the neighbouring Champlain Valley

41 (Cronin et al., 2012), may have contributed to a weakening of thermohaline circulation in

42 the Atlantic Ocean. After $12,900 \mathrm{cal}\left[11,020{ }^{14} \mathrm{C}\right] \mathrm{BP}$, the meltwater presence in the Lake

43 Ontario basin continued to inhibit entry of Champlain seawater into early Lake Ontario.

44 Opening of the North Bay outlet diverted upper Great Lakes water from the lower Great

45 Lakes causing a period $\left(12,300-8,300 \mathrm{cal}\left[10,400-7,500{ }^{14} \mathrm{C}\right] \mathrm{BP}\right)$ of hydrologic closure in 
46 Lake Ontario (Anderson and Lewis, 2012). This change is demarcated by a shift to

47 higher $\delta^{18} \mathrm{O}_{\text {lakewater }}(\sim-7 \%)$, driven in part by strong evaporative conditions in the

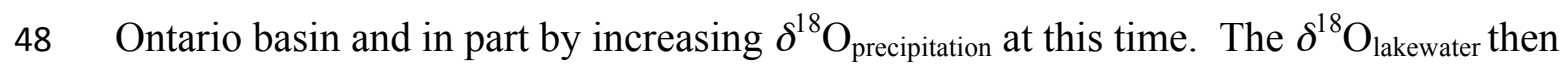

49 fluctuated only slightly upon the eventual return of the upper Great Lakes water during

50 the Nipissing phase at 5,800 cal $\left[5,090{ }^{14} \mathrm{C}\right]$ cal BP (Anderson and Lewis, 2012), after

51 which shelly fauna are no longer preserved in the sediment record.

52

53

54

55

56

57

58

59

60

61

62

63

64

65

66

67

68 


\section{Introduction}

The timing and volume of glacial meltwater outbursts from large glacial lakes in North America are crucial to understanding their potential role in initiating and/or enhancing climatic changes such as the Younger Dryas (YD) by disrupting thermohaline circulation (THC) in the Atlantic Ocean. Carlson and Clark (2012) and references therein provide an excellent review of the current understanding of late-glacial North American meltwater hypotheses. In short, Broecker et al. (1989) initially proposed that the YD $\left(12,900\right.$ cal (calibrated years) $\left[11,020{ }^{14} \mathrm{C}\right.$ (radiocarbon) $]$ BP was triggered by a change in meltwater routing of glacial Lake Agassiz from a southern, Mississippi River outlet to an eastern outlet through the Great Lakes (Fig. 1a). Evidence for eastern drainage of glacial Lake Agassiz at that time has remained elusive, as the opening of a suitable eastern outlet has yet to be established by dating (Clark and Carlson, 2012). There is also a lack of geomorphologic evidence for drainage of glacial Lake Agassiz eastward, such as flood deposits and downcut channels (Teller et al., 2005; Voytek et al., 2012). Northwest drainage of glacial Lake Agassiz to the Arctic Ocean at the start of the YD has also been postulated (Murton et al., 2010; Condron and Winsor, 2012; Fahl and Stein, 2012). A reevaluation by Clark and Carlson (2012) of the optically stimulated luminescence (OSL) dates provided by Murton et al. (2010), however, suggests that the minimum age of a northern outlet was $\sim 12,000$ cal $\left[10,240{ }^{14} \mathrm{C}\right] \mathrm{BP}$, much later than the onset of the YD. Carlson et al. (2007) used geochemical proxies preserved in foraminifera collected from the outer St. Lawrence estuary (Fig.1c) to trace freshwater supply to the Atlantic Ocean. These proxies confirmed a freshwater flux into the Atlantic Ocean and Carlson et al. (2007) concluded that an increase in freshwater flux of $0.06 \pm 0.02$ Sverdrup (Sv) from 
93 western Canada (Lake Agassiz) to the St. Lawrence River would have been sufficient to

94 reduce the Atlantic meridional overturning circulation (AMOC). Levac et al. (2015) used

95 microfossils assemblages (foraminifera, diatoms, dinocysts) from cores recovered from

96 the Cabot Strait, Laurentian Channel and Scotian shelf (Fig. 1b) to suggest meltwater

97 drainage via the St. Lawrence River valley to the Atlantic Ocean before/near the onset of

98 the YD. These findings have reignited discussion concerning possible eastward drainage

99 originating from the Great Lakes region.

100 Other large glacial lakes (Lake Algonquin and Lake Iroquois) also occupied the

101 Great Lakes basin during the period before the YD. Early glacial Lake Algonquin

102 occupied the Huron basin beginning $\sim 13,850$ cal $\left[12,000{ }^{14} \mathrm{C}\right] \mathrm{BP}$ as ice retreated

103 northward (Fig. 1a) (Eschman and Karrow, 1985). During this time period, there was

104 brief connectivity between the Erie and Huron basins, allowing water to enter glacial

105 Lake Iroquois, which occupied the Ontario Basin at that time (Fig. 1a) (Lewis et al.,

106 1994). Shortly thereafter, glacial Lake Algonquin's water level decreased as water was

107 diverted through the ice-free, isostatically depressed, outlet at Fenelon Falls (Kirkfield-

108 Algonquin phase) and drained directly into the Ontario basin (Fig. 1a) (Eschman and

109 Karrow, 1985; Lewis et al., 2012). As the Fenelon Falls outlet isostatically rebounded

110 above the outlet at Port Huron, glacial Lake Algonquin began to flow southward into the

111 Erie basin, and then onward into glacial Lake Iroquois (Lewis et al., 2012). At 12,300

112 cal $\left[10,400{ }^{14} \mathrm{C}\right] \mathrm{BP}$ post-glacial Algonquin lakes began draining through a newly open

113 outlet near North Bay, Ontario bypassing the southern Erie and Ontario basins (Fig. 1b)

114 (Lewis et al., 2012). Meltwater routing during the Kirkfield-Algonquin phase (of glacial

115 Lake Algonquin) through glacial Lake Iroquois could have added an additional $\sim 0.1 \mathrm{~Sv}$ 
116 of freshwater flux to the Atlantic Ocean (Occhietti et al., 2001). Thus, in addition to

117 putative drainage of Lake Agassiz (adding 0.35 Sv of flux; Teller, 1988), contributions

118 from glacial Lake Algonquin and glacial Lake Iroquois could have contributed to

119 suppression of THC and helped to trigger the YD.

120 Lake Ontario sediments provide a special opportunity to revisit the timing and

121 extent of eastward, glacial meltwater movement that passed through its catchment from

122 various upstream sources (Fig. 1c), especially within the context of the detailed water

123 level history for the Lake Ontario basin presented by Anderson and Lewis (2012). With

124 this objective in mind, we use the oxygen isotopic compositions of ostracodes valves and

125 clam shells, together with sediment characteristics, to test for glacial meltwater

126 contributions to Lake Ontario and its ancient equivalents since the retreat of the LIS

$127\left(\sim 16,500 \mathrm{cal}\left[\sim 13,300{ }^{14} \mathrm{C}\right] \mathrm{BP}\right)$. We also use the oxygen isotopic compositions of

128 ostracode valves and clam shells in post-glacial sediments to test for Lake Ontario's

129 response to the period of hydrologic closure and associated environmental conditions

130 posited by Anderson and Lewis (2012) and references therein.

\subsection{Study Area - Lake Ontario Region}

133 Lake Ontario is the smallest in surface area (slightly less than $19,500 \mathrm{~km}^{2}$ ) of the

134 five existing Laurentian Great Lakes (Superior, Michigan, Huron, Erie, Ontario) (Fig.

135 1c). It measures $\sim 290 \mathrm{~km}$ long by $\sim 85 \mathrm{~km}$ wide at its widest point and has a maximum

136 water depth of $244 \mathrm{~m}$ (McFadden et al., 2005). Lake Ontario shares an international

137 border between Canada (Ontario) and the United States of America (New York). 
Lake Ontario's watershed is bounded by the Canadian Shield to the north, the

139 Allegheny Plateau to the south, the Niagara Escarpment to the southwest and west, and

140 the Adirondack Plateau to the east (Hutchinson et al., 1993). The bedrock of the Lake

141 Ontario basin consists of Upper Ordovician shale and limestone, contained within a

142 succession of Cambrian to Carboniferous sedimentary rocks that thickens southward into

143 the Appalachian basin (Hutchinson et al., 1993). At the north and east end of the lake,

144 these sedimentary rocks unconformably overlie the meta-igneous and meta-sedimentary

145 rocks of the Grenville Province of the Canadian Shield (Hutchinson et al., 1993). Two

146 bathymetric ridges (Whitby-Olcott (west) and Scotch Bonnet (east)) subdivide Lake

147 Ontario into three main basins: Niagara (west), Mississauga (central) and Rochester

148 (east). Major water inflow is dominated by the Niagara River to the southwest. It

149 delivers (via Lake Erie) upper Great Lake water to Lake Ontario, which then exits

150 eastward through the St. Lawrence River, presently Lake Ontario's major outlet (Figs. 1b,

151 c). The warm monomictic lake thermally stratifies once per year and has an average

152 water residence time of $\sim 8$ years (McFadden et al., 2005).

153

154

\subsection{Late Quaternary history of the Ontario basin}

155 Correlation of seismic stratigraphy with core lithology and limited geochronology

156 available from various sources, as described below, allows the following description of

157 the sediment record in the Ontario basin. The record began with glacial diamict, possibly

158 a subglacial till composed of deformed glaciolacustrine sediment or flow till. This

159 deposition occurred in the western half of the Ontario basin during retreat of the Port

160 Huron ice lobe at $\sim 16,500$ cal $\left[13,300{ }^{14} \mathrm{C}\right] \mathrm{BP}$ (Hutchinson et al., 1993). Undisturbed 
161 glaciolacustrine deposition, which is characterized by subparallel seismic reflections, 162 began at $\sim 14,000$ cal $\left[12,150{ }^{14} \mathrm{C}\right] \mathrm{BP}$ (Hutchinson et al., 1993). The Ontario basin was 163 deglaciated earlier than the St. Lawrence River drainage farther to the east as the LIS 164 retreated northward. This caused water to be impounded in the Ontario basin, forming 165 glacial Lake Iroquois, which rose to $\sim 35 \mathrm{~m}$ above present Lake Ontario levels (Coakley 166 and Karrow, 1994; Anderson and Lewis, 2012). Growth of glacial Lake Iroquois was 167 regulated by drainage through the Rome Outlet to the Mohawk Valley, with the outflow 168 ultimately travelling to the Atlantic Ocean via the Hudson River valleys (Fig. 1b) (Muller 169 and Prest, 1985, Donnelly et al., 2005).

170 Glacial Lake Iroquois and its successors persisted until $\sim 13,000$ cal $\left[11,100{ }^{14} \mathrm{C}\right]$

$171 \mathrm{BP}$, at which time further retreat of the LIS made eastward flow of the impounded water 172 possible. The water level of glacial Lake Iroquois water was lowered through several 173 stages ultimately resulting in lake levels that were $\sim 15 \mathrm{~m}$ above present lake level in the 174 eastern section of the Ontario basin and below present levels in the west (Coakley and 175 Karrow, 1994; Anderson and Lewis, 2012). The Belleville-Sandy Creek and Trenton176 Skinner Creek lake levels of glacial Lake Iroquois were confluent with neighbouring

177 Lake Vermont in the Champlain basin, which flowed to the Atlantic Ocean via the 178 Hudson River valley (Rayburn et al., 2007; Anderson and Lewis, 2012) (Fig. 1b). The 179 last stage (Trenton), which was confluent with Lake Vermont and Lake Candona, formed 180 an extensive body of freshwater throughout the isostatically-depressed upper St.

181 Lawrence River, Lake Champlain and lower Ottawa River valleys and the Lake Ontario 182 basin (Parent and Occhietti, 1988; Rayburn et al., 2007). Additional ice retreat and 183 removal of the ice dam from the lower St. Lawrence valley released this large volume of 
184 freshwater to the Gulf of St. Lawrence. Arcuate features across the Ottawa valley, 185 however, blocked that potential meltwater pathway prior to $\sim 12,900$ cal $\left[11,000{ }^{14} \mathrm{C}\right] \mathrm{BP}$ 186 (Occhietti, 2007). Thus, delivery of lacustrine water from the Great Lakes basin would 187 have required routing through Lake Ontario.

188 The freshwater that occupied much of lower reaches of the St. Lawrence valley was 189 then replaced by marine water of the Champlain Sea at $\sim 13,000$ cal $\left[11,100{ }^{14} \mathrm{C}\right] \mathrm{BP}$ 190 (Richard and Occhietti, 2005; Rayburn et al., 2007). The transition to the Champlain Sea 191 involved complex hydrological changes that were recorded by shifting microfaunal 192 assemblages in sediment cores from the Champlain Valley, New York (Rayburn et al., 193 2011; Cronin et al., 2012). The earliest part of the transition (Marine Phase I) is defined 194 by foraminiferal species (Rayburn et al., 2011). It was followed by periods of abrupt 195 freshening (Freshwater Phase) in which ostracodes emerged and foraminifera 196 disappeared (Rayburn et al., 2011; Cronin et al., 2012). A Transitional Phase then 197 occurred before the onset of Champlain Sea (Marine Maximum at 12,900 cal [11,020 $\left.198{ }^{14} \mathrm{C}\right] \mathrm{BP}$ ) in which both ostracode and forminifera assemblages co-existed (Rayburn et al., 199 2011; Cronin et al., 2012). Lake Vermont-Champlain Sea sediments also record signals 200 of glacial meltwater floods, including lower $\delta^{18} \mathrm{O}$ of marine benthic foraminifera and 201 appearance of freshwater ostracodes (Rayburn et al., 2011; Cronin et al., 2012). While 202 early Lake Ontario was confluent with the Champlain Sea at this time, eastward forcing 203 of freshwater, facilitated by glacial meltwater input to Lake Ontario and isostatic 204 rebound, likely prevented saltwater invasion into early Lake Ontario (Anderson and 205 Lewis, 2012). 
$207 \mathrm{cal}\left[11,100{ }^{14} \mathrm{C}\right] \mathrm{BP}$ and $12,500 \mathrm{cal}\left[10,500{ }^{14} \mathrm{C}\right] \mathrm{BP}$ (Anderson and Lewis, 2012). This

208 flow likely included discharge (overflow) from glacial Lake Algonquin (Fig. 1a); this

209 water is assumed to have travelled to Lake Ontario initially by a direct path through the

210 Fenelon Falls outlet in the east and later by a more circuitous route through glacial Lake

211 Algonquin's Port Huron outlet in the west (Fig. 1a) (Eschman and Karrow, 1985; Moore

212 et al., 2000; Anderson and Lewis, 2012).

213 From $12,300-8,300 \mathrm{cal}\left[10,400-7,500{ }^{14} \mathrm{C}\right] \mathrm{BP}$, flow from the upper Great Lakes

214 (Superior, Michigan, Huron), and potentially Lake Agassiz overflow, was diverted to the

215 North Bay Outlet (Figs. 1b,c), in response to isostatic rebound (Anderson and Lewis,

216 2012) and ice retreat (Eschman and Karrow, 1985). The outflow then travelled onward

217 via the Ottawa River valley system to the Atlantic Ocean and bypassed the Lake Ontario

218 basin. This rerouting led to hydrologic closure of the lower Great Lakes (Erie and

219 Ontario) and the Lake Ontario water level dropped to the lowest level in its history

220 (Lewis et al., 2012; Anderson and Lewis, 2012). Flow of upper Great Lakes water

221 returned to the lower Great Lakes during the Nipissing phase at 5,800 cal $\left[5,090{ }^{14} \mathrm{C}\right] \mathrm{BP}$

222 (Thompson et al., 2011; Anderson and Lewis, 2012). By then, isostatic rebound had

223 lifted the Lake Huron basin above the outlet at Port Huron, and Lake Ontario water levels

224 began to rise towards present levels (Fig. 1c).

\section{Materials and Methods}

Three piston cores were collected from Lake Ontario during July 15-17, 2008 by 228 the captain and crew of the Canadian Coast Guard Ship (CCGS) Limnos: Core 1335, 
229 Mississauga basin; Core 1336, Rochester basin, and Core 1334, Niagara basin (Fig. 2).

230 The cores were cut into $\sim 1 \mathrm{~m}$ sections onboard and stored in a refrigerator prior to

231 delivery to the University of Rhode Island, where they were halved longitudinally and

232 visible characteristics (colour, consistency, grain size, sedimentary structures including

233 laminations) noted. Sediment colour was described using the Munsell Soil Color Charts

234 and notation (Munsell Color, 2000). The cores were then shipped to the University of

235 Western Ontario where they continue to be stored at $4^{\circ} \mathrm{C}$.

236 A total of 219 ten-cm sections were extracted from the sampling half of the piston

237 cores. The samples were wet-sieved using cold tap water and a combination of four sieve

238 pans $(1.00 \mathrm{~mm}, 500 \mu \mathrm{m}, 250 \mu \mathrm{m}, 125 \mu \mathrm{m})$ to recover ostracodes valves and clams shells;

239 visible organic matter was also collected. The air-dried fossil material was transferred

240 into petri dishes, where the biogenic carbonates were identified and separated by species;

241 ostracodes were counted on the $>250 \mu \mathrm{m}$ sieves. Two species of ostracodes were

242 identified in all three cores, Candona subtriangulata and Fabaeformiscandona caudata;

243 only adult ostracodes were used for abundance determinations. The ostracodes displayed

244 no macroscopic or microscopic evidence of post-mortem transport (e.g., broken/pitted

245 valves), and hence are considered to be autochthonous. Whole clam shells of the

246 Pisidium genus were present only in Cores 1334 and 1335 and were less abundant than

247 clam fragments, which were present in all cores at various intervals.

248 Approximately $0.05 \mathrm{mg}$ of powdered biogenic carbonate was utilized for each

249 oxygen isotopic measurement (five to six ostracode valves were used depending on

250 individual weight; whole clam shells were homogenized when available; when only clam 
251 fragments were present, two to three clam shell fragments were utilized). Only

252 undamaged, adult ostracode valves were analyzed to ensure correct identification.

The oxygen-isotope results are presented using the conventional $\delta$-notation:

254

$$
\delta^{18} \mathrm{O}=\left[\left(\mathrm{R}_{\text {sample }} / \mathrm{R}_{\text {standard }}\right)-1\right](\text { in \%o })
$$

255 where $\mathrm{R}_{\text {sample }}$ and $\mathrm{R}_{\text {standard }}={ }^{18} \mathrm{O} /{ }^{16} \mathrm{O}$ in the sample and standard, respectively. All $\delta$ -

256 values are reported relative to VSMOW, unless otherwise stated. The oxygen-isotope

257 measurements were made in the Laboratory for Stable Isotope Science (LSIS) at the

258 University of Western Ontario, London, Ontario, and were obtained by reaction with

259 orthophosphoric acid $\left(\mathrm{H}_{3} \mathrm{PO}_{4}\right)$ at $90^{\circ} \mathrm{C}$ using a Micromass Multiprep autosampling device

260 coupled to a VG Optima dual-inlet, stable-isotope-ratio mass spectrometer. International

261 standards NBS-19 and NBS-18 were used to provide a two-point calibration curve for the

262 oxygen-isotope compositions relative to VSMOW (Coplen, 1996). Two internal

263 laboratory calcite standards were used to evaluate accuracy and precision of the $\delta^{18} \mathrm{O}$

264 values: $\mathrm{WS}-1=+26.28 \pm 0.15 \%$ o $(\mathrm{SD}, \mathrm{n}=9)$ and Suprapur $=+13.20 \pm 0.07 \%$ (SD, $\mathrm{n}=24)$;

265 these results compare well with their accepted values of $+26.23 \%$ and $+13.20 \%$,

266 respectively.

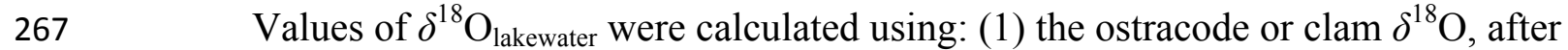

268 first correcting for any vital effect (C. subtriangulata and F. caudata, $+2.2 \%$; no vital

269 effect correction for Pisidium sp. clams; von Grafenstein et al., 1999; Decrouy et al.,

$2702011 \mathrm{a}, 2011 \mathrm{~b}) ;(2)$ an assumed water temperature of $4{ }^{\circ} \mathrm{C}$, and (3) the Friedman and

271 O’Neil (1977) oxygen-isotope geothermometer for the low-Mg calcite - water system.

272 Mineralogy was determined using powder X-ray diffraction (pXRD) at LSIS,

273 using a Rigaku, high brilliance, rotating-anode X-ray diffractometer equipped with a 
274 graphite monochromater and $\mathrm{CoK} \alpha$ radiation produced at $45 \mathrm{kV}$ and $160 \mathrm{~mA}$. A total of

27585 one-cm thick slices were obtained from the sampling portion of the cores. The

276 samples were freeze-dried, finely ground using a mortar and pestle, and back-packed into

277 an Al sample holder to achieve random orientation. Samples were scanned from $2^{\circ}$ to

$27882^{\circ} 2 \theta$ at a scanning rate of $10^{\circ} 2 \theta / \mathrm{min}$. The abundance of each mineral was estimated

279 using the background-subtracted peak height of its most intense diffraction, except where

280 overlap with other phases existed. The form factor used to adjust for crystallinity

281 differences among minerals was $\mathrm{x}$ 1, except for the (001) diffractions of kaolinite $(\times 2)$,

282 chlorite $(\times 2)$ and illite $(\times 4)$.

283 Grain-size analysis was conducted using a Cilas 930e Laser Particle Size

284 Analyzer at the Canada Center for Inland Waters (CCIW), Burlington, Ontario. Forty-six

285 (46) one-cm thick slices from the sampling portion of the cores were freeze-dried and

286 lightly crushed using a mortar and pestle. The homogenized sample was then passed

287 through a $500 \mu \mathrm{m}$ sieve, and a $0.4 \mathrm{mg}$ sub-sample ultrasonicated for 1 minute in $10 \mathrm{ml}$ of

288 a $0.05 \%$ sodium hexametaphosphate solution in the Cilas sample bucket.

289 As previously reported by Hladyniuk and Longstaffe (2015), efforts were made to

290 establish an age-depth model anchored by radiocarbon dates. The paucity of dateable

291 terrestrial macrofossils unfortunately precluded such measurements, except for two

292 intervals (Core 1335, 5.25 m; Core 1336, 4.25m) (Fig. 3). In addition to the terrestrial

293 macrofossils, one interval (Core 1334, 5.45m) contained a sufficient abundance of clam

294 shells for radiocarbon-dating; that date was corrected for the hard water effect (HWE) by

295 subtracting $535 \pm 15$ years (Fig. 3) (Anderson and Lewis, 2012). The dating was

296 performed at the University of Arizona's Accelerator Mass Spectrometer Laboratory, 
297 Tuscon, AZ. Radiocarbon dates have been converted to calibrated ages using INTCAL09

298 (Reimer et al., 2009).

299 The uncertainty surrounding the HWE correction attached to the radiocarbon date 300 obtained for Core 1334 requires special mention. Anderson and Lewis (2012) used

301 modern mollusc shells to obtain this HWE for Lake Ontario. The HWE in dynamic

302 environments like the one under consideration here, however, can be influenced by

303 numerous factors, including local geology, stratification of meltwater over marine water

304 (Hillaire-Marcel, 1981), and non-equilibration of marine water with atmospheric carbon

305 dioxide (Richard and Occhietti, 2005). Many of these considerations can vary temporally

306 and by specific location (Dyke, 2004). Occhietti and Richard (2003) and Richard and

307 Occhietti (2005), for example, showed that errors associated with HWE correction during

308 the time period of interest here can be on the order of thousands of years in the St.

309 Lawrence Lowlands. In the absence of historical measurements for Lake Ontario, the

310 Anderson and Lewis (2012) HWE correction remains the best available information, but

311 it nonetheless should be accepted with appropriate caution.

312 Information from previous Lake Ontario core studies was also used to help

313 construct and strengthen the age-depth model (Hladyniuk and Longstaffe, 2015). These

314 data included pollen stratigraphy (Carmichael et al., 1990; McAndrews, 1994; Pippert et

315 al., 1996), seismic stratigraphy (Hutchinson et al., 1993), magnetic properties

316 (Carmichael et al., 1990) and radiocarbon dates (Silliman et al., 1996; Anderson and

317 Lewis, 2012). Notwithstanding this additional information, uncertainties associated with

318 the age-depth model make impossible correlations between glacial meltwater movement

319 through Lake Ontario and other events, for example the timing of the YD, on timeframes 
320 shorter than 500 years. Accordingly, we limit our discussion to more general

321 consideration concerning water isotope variations in Lake Ontario and its precursors.

323 3. Results

3243.1 Core descriptions

325 The bottom sections $(>17.0 \mathrm{~m})$ of Cores 1335 and 1336 contain minor and 326 pronounced vertical streaking, respectively. These features suggest sediment disturbance

327 during coring, most probably from suction caused by back-pressure on the piston core 328 barrel. These intervals are not considered further.

329 Core photographs depicting the major units described below are provided in the

330 Supplementary data; full photographic coverage of the cores is given in Hladyniuk

331 (2014). The basal sections of Cores $1334(15.0-13.0 \mathrm{~m})$ and $1335(17.0-12.5 \mathrm{~m})$ consist

332 of massive, grayish-brown (10YR 5/2) sediment containing abundant, light gray, silt balls

333 (Fig. 3). The basal section of Core 1336 (17.0-11.5 m) consists of a grayish-brown

334 (10YR 5/2) sediment package containing weak red (2.5YR 5/2), infrequent, mm-thick, 335 parallel laminations that can be correlated with sediments in Cores 1334 and 1335 (Fig.

336 3). A sharp contact marks the appearance of thickly laminated sediments at $12.45 \mathrm{~m}$ in 337 Core 1334, $11.97 \mathrm{~m}$ in Core 1335 and $11.50 \mathrm{~m}$ in Core 1336 (lower dashed line in Fig. 4).

338 Upwards in the core, there are infrequent to frequent, $\mathrm{mm}$ - to $\mathrm{cm}$-thick, weak red (2.5YR $3395 / 2$ ), parallel laminations that increase in thickness and frequency in the western half of 340 the lake. Massive, grayish brown (10YR 5/2) mud transitioning to infrequent, 341 millimeter-thick, weak red (2.5YR 5/2) parallel laminations appears next in the 342 stratigraphic section. The transition from underlying sediments, which is characterized 
343 by cm-thick laminations to thinner, more infrequent laminations, occurs at $10.84 \mathrm{~m}$ in

344 core 1334, $9.43 \mathrm{~m}$ in core 1335 and $9.00 \mathrm{~m}$ in Core 1336. In the west (Niagara basin),

345 Core 1334 transitions from thinly laminated, grayish brown (10YR 5/2) mud to massive,

346 weak red $(2.5 \mathrm{YR} 5 / 2)$ mud $(9.10 \mathrm{~m})$, overlain by featureless massive, grayish brown

347 (10YR 5/2) mud (8.22-8.06 m) (upper dashed line in Fig. 4). Thinly laminated, grayish

348 brown (10YR 5/2) mud (8.05-6.75 m) was deposited above these massive units. This

349 thinly laminated unit was also deposited in the central, Mississauga basin (Core 1335) of

350 Lake Ontario (9.43-6.20 m), but massive muds were not observed. In the east (Rochester

351 basin), Core 1336 transitions from thinly laminated, grayish brown (10YR 5/2) mud to a

352 massive, featureless grayish brown (10YR 5/2) mud (7.00-4.62 m). A conformable,

353 sharp contact occurs at $6.75 \mathrm{~m}$ in Core 1334, $6.20 \mathrm{~m}$ in Core 1335 and $4.62 \mathrm{~m}$ in Core

354 1336; sediment characterized by black, iron sulphide streaks is intercalated with dark

355 grayish brown (10YR 4/2) mud.

356 The basal sediments of Cores 1334 and 1335 correspond to 'Unit B' of

357 Hutchinson et al. (1993) (Fig. 3). A similar mud clast-bearing interval was also described

358 by Pippert et al. (1996), which they termed 'Unit 3'. The contact between the massive,

359 grayish brown (10YR 5/2) unit in Cores 1334 and 1335 and the beginning of the mm-

360 thick parallel laminations is gradational, and marks the transition to 'Unit C' (Hutchinson

361 et al., 1993) (Fig. 3). Unit C also contains a section where laminations increase in

362 frequency and thickness (Hutchinson et al., 1993). This section is followed by sediments

363 showing a decrease in the frequency and thickness of laminations, which has been

364 classified as the earliest stage of 'Unit D' by Hutchinson et al. (1993) (Fig. 3). The

365 conformable, sharp contact, marking the appearance of black, iron-sulphide streaks 
366 demarcates the transition from Unit D to 'Unit E' of Hutchinson et al. (1993) ('Unit 1' of

367 Pippert et al., 1996) (Fig. 3). Deposition of this unit continues presently.

\subsection{Grain size and mineralogy}

370

Median grain size (diameter at $50 \%$ ) in these cores generally increases upwards,

371 but never exceeds $\sim 10 \mu \mathrm{m}$ (Fig. 4). Unit B and the thinly laminated sediments of Unit C

372 have a median grain size of $<3.0 \mu \mathrm{m}$. The transition to Unit D is marked by a slight

373 increase in median grain size across the lake, and occurs above $10.84 \mathrm{~m}$ in Core 1334,

374 above $9.43 \mathrm{~m}$ in Core 1335 and above $9.00 \mathrm{~m}$ in Core 1336 . There are spikes to larger

375 grain sizes within Unit D in all three cores: at $8.90 \mathrm{~m}$ and $7.10 \mathrm{~m}$ in Core 1334 , at $8.10 \mathrm{~m}$

376 in Core 1335, and at $7.30 \mathrm{~m}$ in Core 1336. Unit E sediment gradually increases in median

377 grain size up-core to a maximum of 8.0, 9.5 and $6.0 \mu \mathrm{m}$ from the Niagara to Rochester

378 basin, respectively.

379 The sediment contains varying abundances of quartz, feldspar (plagioclase,

380 potassium feldspar), clay minerals (kaolinite, illite, chlorite) and carbonates (calcite and

381 dolomite) (Fig. 4). Quartz is usually most abundant, varying from 30 to $>80 \%$. Distinct

382 mineralogical differences occur from west to east in Unit B and the basal section of Unit

383 C. In Core 1334, carbonates are in high abundance ( $\sim 30 \%)$ from 15.00-13.00 $\mathrm{m}$ whereas

384 in the same unit in Core $1335(17.00-11.97 \mathrm{~m})$ and Core $1336(17.00-11.50 \mathrm{~m})$, carbonate

385 contents are much lower $(\sim<5 \%)$. Feldspar and clay mineral abundances also vary from 386 west to east in Unit B and the basal section of Unit C. In Core 1334, feldspar abundance

387 increases sharply to $\sim 25 \%$ at $12.9 \mathrm{~m}$ from $\leq 5 \%$ in the underlying interval $(14.0-13.0 \mathrm{~m})$.

388 Feldspar abundance remains at $\sim 15 \%$ in Cores 1335 and 1336 during the same period. 
389 In Unit B and the basal section of Unit C, clay mineral contents increase from west ( 20

$390 \%)$ to east $(>30 \%)$. Unit D in Core 1334 is marked by an upward decrease in carbonate

391 abundance ( $\sim 30$ to $15 \%)$, whereas in Cores 1335 and 1336 carbonate abundance

392 increases upwards from 15 to $30 \%$. Carbonate abundances in Unit E vary across the

393 lake. In Core 1334, carbonate content decreases relative to unit D (from 20 to $<5 \%$ ),

394 whereas in Cores 1335 and 1336, carbonate contents increase initially to a maximum of

$39540 \%$ but then gradually decrease to $<5 \%$. Clay and feldspar contents remain constant in

396 Unit E whereas quartz abundances generally increase upwards.

397

$398 \quad 3.3$ Biostratigraphy

399 Two species of ostracodes, C. subtriangulata and F. caudata, and Pisidium sp.

400 clams (whole) shells were present in Cores 1334 and 1335 and clam shell fragments were

401 present in all cores (Fig. 4). We have defined three biostratigraphic zonations. Zone 1

402 has $C$. subtriangulata abundances $<0.3$ valves per gram sediment (v/g), and occurs at

$403>11.10 \mathrm{~m}$ in Core 1334, $>9.65 \mathrm{~m}$ in Core 1335 and $>7.50 \mathrm{~m}$ in Core 1336. Zone 2 has

404 higher C. subtriangulata abundances to a maximum of $1.56 \mathrm{v} / \mathrm{g}$ in Core 1334 (7.10 m),

$4050.96 \mathrm{v} / \mathrm{g}$ in Core $1335(6.25 \mathrm{~m})$ and $1.50 \mathrm{v} / \mathrm{g}$ in Core $1336(5.05 \mathrm{~m})$. Zone 3 contains both

406 ostracode species and clams. There is a marked decline in the abundance of $C$.

407 subtriangulata in Zone 3 along with the sporadic appearance of $F$. caudata $(<0.08 \mathrm{v} / \mathrm{g})$ in

408 low abundances. Both whole and fragments of Pisidium sp. clam shells appear at $7.80 \mathrm{~m}$

409 in Core 1334 and $6.05 \mathrm{~m}$ in Core 1335. Only fragmented clam shells appear in Core 1336

$410-$ at $4.45 \mathrm{~m}$. Ostracodes and clam species disappear from the sediment record at $2.8 \mathrm{~m}$ in

411 Core 1334, $3.0 \mathrm{~m}$ in Core 1335 and $1.6 \mathrm{~m}$ in Core 1336. 


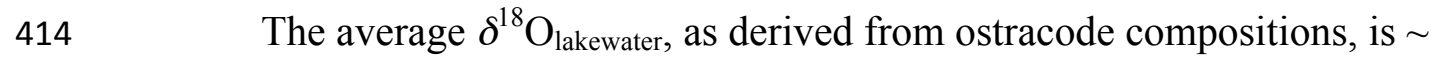

$415-17.5 \pm 0.8 \%(\mathrm{SD} ; \mathrm{n}=81)$ in sediments $>10.84 \mathrm{~m}$ in Core $1334,>9.43 \mathrm{~m}$ in Core 1335 and

$416>9.00 \mathrm{~m}$ in Core 1336 (Fig. 4). Variation in $\delta^{18} \mathrm{O}_{\text {lakewater increases from west to east: Core }}$

$4171334,-17.7 \pm 0.2 \%$ o $(S D ; n=14)$; Core 1335, $-17.8 \pm 0.7 \%$ (SD; $n=36)$; Core 1336,-

$41817.2 \pm 0.9 \%$ (SD; $n=31)$. An analysis of variance (ANOVA) of $\delta^{18} \mathrm{O}_{\text {lakewater }}$ for these

419 intervals showed significant variation among the three cores $(F$-value $=6, p$-value $=0.005)$.

420 A post-hoc Tukey's test found significant variation between Core 1336 and the other two

421 cores (Core 1334; $p$-value $=0.03$, Core 1335; $p$-value=0.02), but not between Cores 1334

422 and 1335 ( $p$-value $=0.1)$.

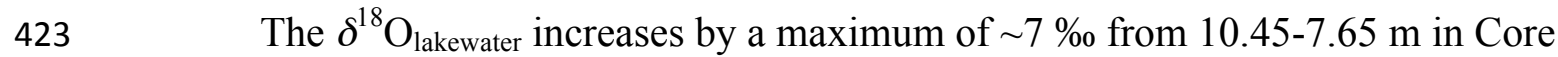

$4241334,9.05-8.45 \mathrm{~m}$ in Core 1335, and 8.85-6.85 $\mathrm{m}$ in Core 1336. A decrease in

$425 \delta^{18} \mathrm{O}_{\text {lakewater }}$ then interrupts the overall trend of increasing oxygen isotopic compositions,

426 beginning at $7.45 \mathrm{~m}$ in Core $1334,8.25 \mathrm{~m}$ in Core 1335 and $6.65 \mathrm{~m}$ in Core 1336.

427 The increase in $\delta^{18} \mathrm{O}_{\text {lakewater }}$ resumes following this brief excursion to more

428 negative values (Fig. 4). For ostracodes, the calculated $\delta^{18} \mathrm{O}_{\text {lakewater }}$ reaches values as high 429 as $-9.1 \%$ in Core $1334,-6.7 \%$ in Core 1335 , and $-5.9 \%$ in Core 1336. Still higher $430 \delta^{18} \mathrm{O}_{\text {lakewater }}$ is recorded by the clams: $-4.2 \%$ in Core $1334,-4.0 \%$ in Core 1335 , and $4314.5 \%$ in Core 1336. Modern Lake Ontario, by comparison, has a $\delta^{18} \mathrm{O}_{\text {lakewater }}$ of $-6.6 \%$ 432 (Longstaffe et al., 2011). Clam shells and fragments in Core 1334 initially record similar $433 \delta^{18} \mathrm{O}_{\text {lakewater }}$ as ostracodes but trend toward more ${ }^{18} \mathrm{O}$-rich compositions after the 434 disappearance of ostracodes. In Core 1335, there is an initial $\sim 1 \%$ offset between clam 
435 and ostracode $\delta^{18} \mathrm{O}_{\text {lakewater, }}$, which increases up-core to $\sim 2 \%$ by final appearance of both

436 species. Clam shell fragments in Core 1336, which appear later than in Cores 1334 and

4371335 , exhibit a $\sim 1 \%$ offset between $\delta^{18} \mathrm{O}_{\text {lakewater, as inferred from clam versus ostracode }}$

438 oxygen isotopic compositions.

440 4. Discussion

4414.1 Glacial period $\left(16,500-13,260 \mathrm{cal}\left[13,300-11,100{ }^{14} \mathrm{C}\right] \mathrm{BP}\right)$

442 The lowermost portions of Cores 1334 and 1335 contain sediments (Unit B or

443 Unit 3, following Hutchison et al., 1993 and Pippert et al., 1996, respectively) deposited

444 in the Niagara and Mississauga basins during the retreat of Port Huron ice. Age control

445 for these sediments is difficult to establish because of the absence of dated pollen

446 horizons and the paucity of dateable organic material. In its absence, linear extrapolation

447 below the inferred contact between Units B and C $\left(14,655\right.$ cal $\left.\left[12,500{ }^{14} \mathrm{C}\right] \mathrm{BP}\right)$

448 (Hutchinson et al., 1993) has been used to estimate that the lowermost Unit B sediments

449 recovered in this study are as old as $\sim 16,500 \mathrm{cal}\left[13,300{ }^{14} \mathrm{C}\right] \mathrm{BP}$.

450 These sediments are characterized by low abundances of C. subtriangulata, very

451 fine grain size $(<3 \mu \mathrm{m})$ and low $\delta^{18} \mathrm{O}_{\text {lakewater }}(<-17 \%)$. Traditionally, these sediments

452 have been interpreted as glacial diamict, possibly a subglacial till composed of deformed

453 glaciolacustrine sediment or flow tills associated with the retreating LIS (Hutchinson et

454 al., 1993). The presence of C. subtriangulata in these sediments, albeit at low

455 abundances, supports a deformed glaciolacustrine origin for much of Unit B.

456 There are noteworthy mineralogical differences between the Niagara and

457 Mississauga basin sediments deposited in Unit B (Fig. 4) that point to differences in their 
458 sources. The higher proportions of feldspar and clay minerals in the Mississauga basin

459 sediments (Core 1335) likely reflect increased contribution from the Precambrian

460 Canadian Shield. The higher carbonate abundances in Niagara basin Core 1334 (>30 \%)

461 relative to Core $1335(<5 \%)$ likely indicate greater input from glacial Lake Ypsilanti,

462 which was enriched in Paleozoic carbonate detritus originating in both the Erie and

463 Huron basins. At 16,000-15,300 cal $\left[13,140-12,975{ }^{14} \mathrm{C}\right] \mathrm{BP}$, during the Mackinaw

464 interstadial, the LIS retreated farther east into the Ontario basin, which allowed glacial

465 Lake Ypsilanti (Erie basin) to drain through its outlet at the Fort Erie-Buffalo sill and

466 entered the Lake Ontario basin via Niagara Falls (Fig. 1a) (Lewis et al., 2012). This brief

467 period of connectivity between the Erie and Ontario basins allowed ancestral Lake

468 Ontario to receive glacial meltwater and sediment from the carbonate-rich Erie basin.

469 Ice readvanced after the Mackinaw interstadial, ending the glacial Lake Ypsilanti

470 phase and severing connectivity between the Erie and Ontario basins (Calkin and

471 Feenstra, 1985; Lewis et al., 2012). Ancestral Lake Erie rose to the Lake Whittlesey

472 level and overflowed westward to the Michigan basin from 15,300-14,500 cal [12,975-

$\left.47312,410{ }^{14} \mathrm{C}\right] \mathrm{BP}$ (Calkin and Feenstra, 1985; Lewis et al., 2012). Subglacial deposition

474 became dominant in the Ontario basin during this period. The increase in feldspar

475 content in Core 1334 is consistent with glacial sediment from eastern sources. The

476 variability in $\delta^{18} \mathrm{O}_{\text {lakewater }}$ during this time interval may be related to the instability of the

477 LIS. The variability in Core $1335(-17.9 \pm 0.6 \%$ ) may indicate incomplete mixing of an

478 irregular meltwater flux from the LIS to the east and north. The short time scale (on the

479 order of weeks) over which an ostracode acquires its oxygen isotope signal from

480 lakewater makes the recording of such a signal possible. While slightly lower $\delta^{18} \mathrm{O}_{\text {lakewater }}$ 
481 variability in Core $1334(-17.5 \pm 0.4 \%$ ) may suggest that perturbations in meltwater flux

482 were more limited farther from Core 1335, the isotopic differences between the cores are 483 not statistically significant.

484 Ice remaining from the northeastward retreating LIS blocked any possible flow of 485 meltwater to the St. Lawrence River, thus facilitating formation of glacial Lake Iroquois $486\left(\sim 14,000 \mathrm{cal}\left[12,150{ }^{14} \mathrm{C}\right] \mathrm{BP}\right)$. Glacial Lake Iroquois sediments (Unit C) were observed 487 in the cores from all three Lake Ontario basins. The near uniform abundances of $C$. 488 subtriangulata indicate cold $\left(\sim 4^{\circ} \mathrm{C}\right)$, dilute $(<90 \mathrm{mg} / 1$ total dissolved solids), and 489 oxygenated (>5.6 mg/l) benthic conditions (Delorme, 1978; 1989). The low median 490 grain size $(<3 \mu \mathrm{m})$ reflects deposition in a deep, low energy, lacustrine environment, 491 which is consistent with glacial Lake Iroquois levels having been $\sim 35 \mathrm{~m}$ higher than at 492 present (Coakley and Karrow, 1994).

493 The relative contributions of different glacial meltwater sources (LIS, glacial 494 Lake Algonquin) to glacial Lake Iroquois probably varied over time. From 14,000$49513,000 \mathrm{cal}\left[12,150-11,100{ }^{14} \mathrm{C}\right] \mathrm{BP}$, outflow from glacial Lake Algonquin bypassed the 496 Erie basin and flowed directly into glacial Lake Iroquois via the Fenelon Falls Outlet 497 (Anderson and Lewis, 2012) (Figs. 1a, 2). Data for ostracodes from Lake Simcoe and 498 Lake Huron sediments suggest that glacial Lake Algonquin $\delta^{18} \mathrm{O}_{\text {lakewater }}$ input ranged from $499-19$ to $-17.5 \%$ (Bumstead et al., 2009; Macdonald and Longstaffe, 2008). This 500 meltwater, which entered glacial Lake Iroquois via its northeastern inlet, had a short and 501 direct path to outflow through the Mohawk River valley (Figs. 1a, 2). Core 1336 ($502 \quad 18.1 \pm 0.7 \%$ ) is situated very close to the northeastern inlet to Lake Ontario (Fig. 2), 503 unlike Core $1334(-17.8 \pm 0.3)$ and to a lesser extent, Core $1335(-16.8 \pm 2.0 \%$ \%). The 
504 higher variance in $\delta^{18} \mathrm{O}_{\text {lakewater }}$ recorded by Cores 1335 and 1336 and the overall lower $505 \delta^{18} \mathrm{O}_{\text {lakewater }}$ of Core 1336 relative to Core 1334 can be explained by their locations. In 506 this scenario, the larger $\delta^{18} \mathrm{O}_{\text {lakewater variations in Cores } 1335 \text { reflect a dynamic lacustrine }}$ 507 regime mostly resulting from fluctuating contributions from: (i) the west (regional $508 \delta^{18} \mathrm{O}_{\text {precipitation }}=-16.5 \%$; Edwards et al., 1996), (ii) the east-central outlet of glacial Lake 509 Algonquin (-19 to $-17 \%$ ), and (iii) direct LIS runoff ( -35 to $-25 \%$ ) (Ferguson and 510 Jasechko, 2015) from immediately to the northeast. The lowest $\delta^{18} \mathrm{O}_{\text {lakewater }}$ in eastern 511 glacial Lake Iroquois, in particular, likely reflects increased meltwater delivery directly 512 from the LIS, an observation also consistent with higher feldspar and clay abundances in 513 Core 1336 relative to Cores 1334 and 1335 at this time.

$514 \quad$ The LIS retreat from the St. Lawrence lowland shortly after $\sim 13,260$ cal $[11,360$

$515{ }^{14} \mathrm{C}$ ] BP led to eastward drainage of glacial Lake Iroquois and lowstand conditions in the 516 Ontario basin (Anderson and Lewis, 2012) that were likely further enhanced by 517 termination of direct glacial meltwater supply from the LIS. These changes coincided 518 with a regional cold/dry period (Lewis et al., 2008). The ensuing rapid increase in $519 \delta^{18} \mathrm{O}_{\text {lakewater }}$ from -19 to $-12 \%$ (Fig. 4) may be representative of these conditions. If so, 520 the increase in $\delta^{18} \mathrm{O}_{\text {lakewater }}$ would reflect elimination of direct, LIS, low- ${ }^{18} \mathrm{O}$ glacial 521 meltwater input and perhaps some evaporative ${ }^{18} \mathrm{O}$-enrichment. From the isotopic data 522 alone, it is impossible to rule out an ${ }^{18} \mathrm{O}$-rich influx from the confluent Champlain Sea at $523 \sim 12,900 \mathrm{cal}\left[11,000{ }^{14} \mathrm{C}\right] \mathrm{BP}$ (Anderson and Lewis, 2012). There is no evidence for 524 marine invasion of Lake Ontario, however, such as extirpation of the salinity-sensitive $C$. 525 subtriangulata or appearance of marine foraminifera or ostracodes. 
527

528

529

530

531

532

533

534

535

536

537

538

539

540

541

542

543

544

545

546

547

548

549

4.2 Final glacial meltwater influx $\left(13,000-12,500 \mathrm{cal}\left[11,100-10,500{ }^{14} \mathrm{C}\right] \mathrm{BP}\right)$

The rise in $\delta^{18} \mathrm{O}_{\text {lakewater }}$ that began at a suggested age of $\sim 13,260$ cal $\left[11,360{ }^{14} \mathrm{C}\right]$

BP was not continuous. In particular, $\delta^{18} \mathrm{O}_{\text {lakewater }}$ in Core 1335 decreased from $\sim-12$ to $14 \%$ starting at $8.45 \mathrm{~m}$ and continued to decrease until $7.05 \mathrm{~m}$ (Fig. 4). This decline could reflect a change in the oxygen isotopic composition of regional precipitation and/or increased influx of low- ${ }^{18} \mathrm{O}$ glacial meltwater. The first possibility is unlikely. While pollen and wood cellulose records indicate cold and dry conditions at this time, $\delta^{18} \mathrm{O}_{\text {precipitation }}$ derived from analysis of coeval wood cellulose rose from -17 to $-15 \%$ (Edwards and Fritz, 1986; Edwards and McAndrews, 1989; Edwards et al., 1996). In contrast, increased glacial meltwater input from upstream sources (glacial Lake

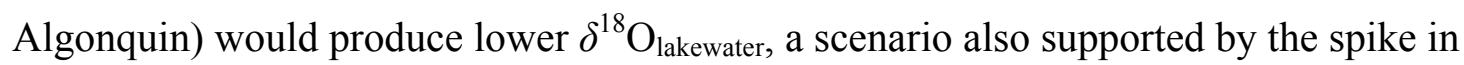
median sediment grain size $(\sim 2.5$ to $9 \mu \mathrm{m})$ measured for this time (Fig. 4). Similar decreases in $\delta^{18} \mathrm{O}_{\text {lakewater }}$ and increases in median grain size are recorded at $7.65 \mathrm{~m}$ in Core 1334 and $6.85 \mathrm{~m}$ in Core 1336 (Fig. 4).

Anderson and Lewis (2012) reported inundation of ancient Lake Ontario by glacial meltwater at $12,800 \mathrm{cal}\left[10,965{ }^{14} \mathrm{C}\right] \mathrm{BP}$. Its sources and routing into and out of Lake Ontario, however, have been largely unexplored. Glacial meltwater input from glacial Lake Algonquin (Kirkfield phase) via the Fenelon Falls outlet, which established connectivity with the Ontario basin at 13,000 cal $\left[11,110{ }^{14} \mathrm{C}\right] \mathrm{BP}$ (Lewis et al., 2012), could account for this interval of lower $\delta^{18} \mathrm{O}_{\text {lakewater. }}$

The ultimate source of glacial meltwater input into Lake Ontario that caused the decrease in $\delta^{18} \mathrm{O}_{\text {lakewater }}$ from -12 to $-14 \%$ is of interest, given that this time period may coincide with the beginning of the YD. As noted earlier, Broecker et al. (1989) 
550 hypothesized a change in meltwater routing out of glacial Lake Agassiz from southward

551 (Gulf of Mexico) to eastward (Great Lakes Basin) during the YD. Unfortunately, oxygen

552 isotopes do not provide for a clear distinction between meltwater contributions to Lake

553 Ontario from glacial Lake Agassiz versus other glacial lake(s).

554 The location of the putative outlet for the final pulse of glacial meltwater received

555 by Lake Ontario is equally enigmatic. One possibility is an eastern outlet into the

556 Champlain Valley. Near the onset of the YD $\left(13,100\right.$ cal $\left.\left[11,170{ }^{14} \mathrm{C}\right] \mathrm{BP}\right)$, as discussed

557 earlier, Lake Vermont was transitioning to the Champlain Sea before full onset of the

558 Champlain Sea (Marine Maximum at 12,900 cal [11,020 $\left.{ }^{14} \mathrm{C}\right] \mathrm{BP}$ ) (Rayburn et al., 2011;

559 Cronin et al., 2012). Values of $\delta^{18} \mathrm{O}_{\text {ostracode }}$ measured by Cronin et al. (2012) for the

560 Freshwater and Transitional phases during the Lake Vermont-Champlain Sea transition

561 are very similar to those recorded in Lake Ontario (-14 to $-13 \%$ o). Based on terrestrial

562 radiocarbon dates and the New England varve record, Rayburn et al. (2011) and Cronin et

563 al. (2012) have attributed these changes to glacial meltwater floods (from 13,100-12,900

$\left.564\left[11,170-11,020{ }^{14} \mathrm{C}\right] \mathrm{cal} \mathrm{BP}\right)$ originating from glacial Lake Agassiz. Notwithstanding the

565 potentially large errors associated with the age-depth model, the increase in meltwater

566 supply beginning at 13,000 $\left[11,100{ }^{14} \mathrm{C}\right]$ cal BP observed here for the Ontario basin, and

567 its possible contribution to climate change, becomes especially interesting in light of the

568 meltwater influxes reported in the Atlantic Ocean during the onset of the YD (Levac et

569 al., 2015).

570 The lowering of Ontario basin $\delta^{18} \mathrm{O}_{\text {lakewater }}$ to $-14 \%$ likely lasted until $\sim 12,500$ cal

$571\left[10,500{ }^{14} \mathrm{C}\right] \mathrm{BP}$, but there is no record of meltwater entry into the Champlain Sea from

$572 \sim 12,900 \mathrm{cal}\left[11,020{ }^{14} \mathrm{C}\right] \mathrm{BP}$ to $11,400 \mathrm{cal}\left[10,000{ }^{14} \mathrm{C}\right] \mathrm{BP}$. Cronin et al. $(2012)$ 
573 postulated that the impact of freshwater events on Champlain Sea salinity must have been

574 swift and immense, and that return to full marine conditions was rapid. The entry of

575 meltwater pulses of this magnitude into Lake Ontario likely prevented incursion of

576 marine water from the east (Anderson and Lewis, 2012). In the absence of substantial

577 meltwater outflow after $12,900 \mathrm{cal}\left[11,020{ }^{14} \mathrm{C}\right] \mathrm{BP}$, water levels in the Ontario basin

578 likely rose to accommodate the incoming glacial meltwater. The sharp increase in

$579 \delta^{18} \mathrm{O}_{\text {lakewater }}$ that resumed towards the end of this interval is most simply explained by

580 cessation of low- ${ }^{18} \mathrm{O}$ meltwater input.

581 A more robust age model, supported by paleomagnetic secular variation records,

582 is needed to improve current age control on this postulated meltwater incursion into the

583 Ontario basin. Nonetheless, our current ideas correlate well with the lake-level history

584 provided by Anderson and Lewis (2012) (Fig. 5). While acknowledging the potential

585 errors associated with the current age-depth model, it remains that the only evidence of a

586 meltwater flood/routing event passing through the Ontario basin to the Atlantic Ocean is

587 connected to the initial drawdown of glacial Lake Iroquois (Donnelly et al., 2005) and

588 recorded in Lake Ontario sediment beginning at $\sim 13,260$ cal $\left[11,360{ }^{14} \mathrm{C}\right] \mathrm{BP}$.

589 The subsequent increase in meltwater supply to the Ontario basin from glacial

590 Lake Algonquin, which is associated with a decrease in $\delta^{18} \mathrm{O}_{\text {lakewater }}$ from -12 to $-14 \%$,

591 occurred at $\sim 13,000$ cal $\left[11,110{ }^{14} \mathrm{C}\right] \mathrm{BP}$ and lasted $\sim 500$ years. Within the limitations of

592 the current age-depth model, we note that the earliest part of this decrease in $\delta^{18} \mathrm{O}_{\text {lakewater }}$

593 potentially correlates with periods of freshening during the Lake Vermont-Champlain Sea

594 transition phase (Cronin et al., 2012). This may indicate a link between Lake Ontario and

595 the events in the Atlantic Ocean observed by Carlson et al. (2007) and Levac et al. 
596 (2015). The lack of evidence, however, for sustained, freshening of the Champlain Sea

597 after this time period $\left(\sim 12,900 \mathrm{cal}\left[11,020{ }^{14} \mathrm{C}\right]\right.$ BP to $\left.12,500 \mathrm{cal}\left[10,500{ }^{14} \mathrm{C}\right] \mathrm{BP}\right)$

598 suggests that a large portion of meltwater reaching Ontario basin remained there, and

599 hence would have had little impact on Champlain Sea salinity or thermohaline circulation

600 in the Atlantic Ocean.

601

602

4.3 Post-glacial transition and hydrologic closure $\left(12,500-8,300 \mathrm{cal}\left[10,500-7,500{ }^{14} \mathrm{C}\right]\right.$

$603 \quad B P]$

604 Following the final influx of glacial meltwater into Lake Ontario, glacial Lake

605 Algonquin outlets at Port Huron and Fenelon Falls were abandoned and outflow diverted

606 to a newly opened northern outlet near North Bay, Ontario (Eschman and Karrow, 1985).

607 The continuing increase in Ontario basin $\delta^{18} \mathrm{O}_{\text {lakewater }}$ largely reflects the cessation of

608 meltwater influx (Fig. 4). Values of $\delta^{18} \mathrm{O}_{\text {lakewater }}$ inferred from ostracode compositions

609 reached as high as $-9.8 \%$ in Core 1334, $-9.9 \%$ in Core 1335 and $-9.0 \%$ in Core 1336

610 by the time of transition from Units D to E. This lithological transition demarcates the

611 end of glacial influence and dates to $\sim 12,300$ cal $\left[10,400{ }^{14} \mathrm{C}\right]$ (Hutchinson et al., 1993;

612 Pippert et al., 1996). At this point Lake Ontario entered closed basin conditions

613 according to Anderson and Lewis (2012); they noted that the lowest water levels were a

614 product of evaporative stress, and lasted until $\sim 10,000 \mathrm{cal}\left[8,880{ }^{14} \mathrm{C}\right] \mathrm{BP}$. The

615 appearance of the black streaks (sulphide) at the transition from Units D to E suggests

616 reducing conditions, perhaps caused by an increased demand for oxygen by organisms

617 (Pippert et al., 1996). Water levels gradually rose after that time as evaporative stress

618 eased, but hydrologic closure persisted until $\sim 8,300$ cal $\left[7,500{ }^{14} \mathrm{C}\right] \mathrm{BP}$. 
The biostratigraphy and $\delta^{18} \mathrm{O}_{\text {lakewater }}$ of Ontario basin sediments support Anderson

620

621

622

623

624

625

626

627

628

629

630

631

632

633

634

635

636

637

638

639

640

641

and Lewis' (2012) model (Fig. 5). During the early Holocene (until 8,300 cal [7,500

$\left.{ }^{14} \mathrm{C}\right] \mathrm{BP}$ ), southern Ontario was influenced mainly by Arctic air masses over the

northward-retreating LIS (Edwards et al., 1996). This Arctic influence produced a

cold/dry period in southern Ontario, with relative humidity levels $20 \%$ lower than at

present (Edwards et al., 1996). Over this time period, $\delta^{18} \mathrm{O}_{\text {precipitation }}$ in southern Ontario

increased from -15 to $-11 \%$ (Edwards et al., 1996). Such precipitation compositions in

the regional watershed would be expected to yield $\delta^{18} \mathrm{O}_{\text {lakewater }}$ no higher than $\sim-12.5$ to -

$8.5 \%$, based on the present spread of $\sim 2.5 \%$ between modern Lake Ontario and

precipitation in the region (Longstaffe et al., 2011). Instead, $\delta^{18} \mathrm{O}_{\text {lakewater }}$ had already

increased to a maximum of $-7 \%$ (ostracodes) to $-6 \%$ (clam shell fragments) (Figs. 4,

5). As such, $\delta^{18} \mathrm{O}_{\text {lakewater }}$ during this stage of hydrologic closure point to a greater role for evaporative ${ }^{18} \mathrm{O}$-enrichment than is presently the case.

The rate of increase in $\delta^{18} \mathrm{O}_{\text {lakewater }}$ appears to slow before the end of hydrologic closure (Figs. 4, 5) at 8,300 cal $\left[7,500{ }^{14} \mathrm{C}\right] \mathrm{BP}$. There is little change in $\delta^{18} \mathrm{O}_{\text {lakewater }}$ recorded by ostracodes, including $F$. caudata that appeared in Core 1336 , and $<2 \%$ increase (to $-5 \%$ ) in all cores, based on clams. These results are consistent with the easing of evaporative conditions in the Ontario basin proposed by Anderson and Lewis (2012), as humidity and precipitation levels gradually increased with the onset of warmer conditions.

Low water levels during hydrologic closure were accompanied by appearance of Pisidium sp. clams (Cores 1334 and 1335; fragments only in Core 1336) and F. caudata in Core 1336, which marks a significant change in the benthic biological community. 
642 This change coincides with hydrologic closure of the Ontario basin and a peak in 643 ostracode productivity in Cores 1334 and 1335. Shallower water is likely key in the 644 emergence of clams (Delorme, 1989). They appeared first in Cores 1334 and 1335, 645 initially as shell fragments, likely transported from shallower water, then as whole shells 646 presumed to have been deposited in situ when the basins were at their shallowest (current 647 water depths: Core 1334, $110 \mathrm{~m}$; Core 1335, $192 \mathrm{~m}$ ).

649 (Fig. 4). Shallower water conditions developed later in the vicinity of Core 1336 (current 650 depth, $222 \mathrm{~m}$ ) than elsewhere in Lake Ontario (Anderson and Lewis, 2012). The 651 appearance of $F$. caudata (and disappearance of $C$. subtriangulata) in Core 1336 suggests 652 that bottom waters in this deeper basin became less oxygenated compared to the western 653 portion of the lake. Although not likely anoxic, the Rochester basin was likely 654 experiencing conditions similar to those found in present Lake Erie (Delorme, 1978). 655 Loss of C. subtriangulata typically occurs as dissolved oxygen concentrations fall below $6565.6 \mathrm{mg} / \mathrm{l}$. Successive years of low dissolved oxygen cause extirpation of $C$.

657 subtriangulata because of its relatively long life cycle (1 year) and its inability to reach 658 maturity and lay eggs (Delorme, 1978). F. caudata, by comparison, has lower minimum 659 dissolved oxygen requirements (2.3 mg/l). Its shorter life cycle (3 to 4 weeks) and 660 associated egg production ensures proliferation for several generations (Delorme, 1978). 661 In Core 1334, the first clams record $\delta^{18} \mathrm{O}_{\text {lakewater }}$ similar to coexisting ostracodes.

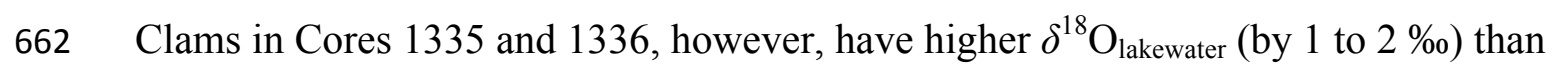
663 ostracodes from the same intervals. These differences could point to the onset of 664 monomictic conditions in ancient Lake Ontario, as has been inferred previously from the 
665 carbon isotopic compositions of these fauna (Hladyniuk and Longstaffe, 2015). Clams

666 may have grown in shallower water enriched in ${ }^{18} \mathrm{O}$ by evaporation prior to lake overturn 667 and prior to their transport to deeper parts of the basin after death. The in-situ ostracode 668 valves, by comparison, carry deeper, bottom-water $\delta^{18} \mathrm{O}_{\text {lakewater }}$ signatures characteristic of 669 well-mixed conditions.

670

6714.4 Post-Hydrologic Closure (since 8,300 cal [7,500 $\left.\left.{ }^{14} \mathrm{C}\right] \mathrm{BP}\right]$

672 With the continued retreat and eventual collapse of the LIS, southern Ontario 673 became more strongly influenced by marine tropical air masses originating in the Gulf of 674 Mexico. This caused the regional climate to shift from the cold and dry conditions 675 described earlier, to warm and dry $\left(\sim 8,300\right.$ to 6,800 cal $\left[7,500\right.$ to $\left.\left.6,000{ }^{14} \mathrm{C}\right] \mathrm{BP}\right)$, and 676 then to warm and wet (at $\sim 6,800 \mathrm{cal}\left[6,000{ }^{14} \mathrm{C}\right] \mathrm{BP}$ ) (Edwards et al., 1996). Lake levels 677 began to increase at $\sim 8,300$ cal $\left[7,500{ }^{14} \mathrm{C}\right] \mathrm{BP}$ (Anderson and Lewis, 2012). The 678 Nipissing phase at $\sim 5,800 \mathrm{cal}\left[5,090{ }^{14} \mathrm{C}\right] \mathrm{BP}$ is typically used to mark the return of upper 679 Great Lakes drainage to Lakes Erie and Ontario (Anderson and Lewis, 2012), as warmer 680 and wetter conditions were fully established. Evaluating these changes isotopically, 681 however, is difficult because suitable samples were not present at these inferred ages. 682 The ostracode record for Core 1336 suggests that $\delta^{18} \mathrm{O}_{\text {lakewater }}$ was virtually identical to the 683 present value of $-6.6 \%$ just before the disappearance of the biogenic carbonate record 684 (Figs. 4, 5). Clam shells continued to record higher $\delta^{18} \mathrm{O}_{\text {lakewater }}(\sim-5 \%$ ) with perhaps 685 even more ${ }^{18}$ O-rich, shallow water conditions in Core 1335 at $\sim 3.5 \mathrm{~m}$. Results for a 686 coexisting in situ F. caudata valve at this depth suggest $\delta^{18} \mathrm{O}_{\text {lakewater }}$ of at least $-5 \%$. 
688 the most general of terms. By the time of the Nipissing phase, climatic and hydrological

689 conditions in the Ontario basin, at least those that are captured by the $\delta^{18} \mathrm{O}_{\text {lakewater }}$ signal,

690 were not significantly different from the present time. The shelly fauna then disappear

691 from the sediment records examined here at $\sim 3 \mathrm{~m}$ in Core 1334, 2 $\mathrm{m}$ in Core 1335 and

$692 \sim 1 \mathrm{~m}$ in Core1336 (Fig. 4). Low sedimentation rates likely caused biogenic carbonates to

693 dissolve before they could be buried, an observation supported by a decrease in detrital

694 carbonate contents over this depth interval (Fig. 4).

695

696 5. Conclusions

697 The oxygen isotopic compositions of ostracodes and clams, supplemented by 698 mineralogical and grain-size information, provide insight concerning the extent, duration 699 and origin of glacial meltwater input into ancient Lake Ontario since the beginning of the 700 retreat of the LIS $\left(\sim 16,500\right.$ cal $\left.\left[13,300{ }^{14} \mathrm{C}\right] \mathrm{BP}\right)$. Ostracode proxies for $\delta^{18} \mathrm{O}_{\text {lakewater }}(<-17$

$701 \%$ ) from the lowermost sediments in the western and central portions of Lake Ontario 702 confirm a substantial glacial meltwater presence when the LIS was in close proximity $703\left(16,000-15,300 \mathrm{cal}\left[13,140-12,975{ }^{14} \mathrm{C}\right] \mathrm{BP}\right)$. Variations in detrital carbonate, clay and 704 feldspar contents between the western and central portions of the Ontario basin indicate 705 connectivity with ancient Lake Erie (glacial Lake Ypsilanti) at this time. Continued low $706 \delta^{18} \mathrm{O}_{\text {lakewater }}(<-17.5 \%)$ coupled with a change in detrital mineralogy and increased 707 variability in $\delta^{18} \mathrm{O}_{\text {lakewater }}$ mark the end of connectivity with Lake Ypsilanti $(15,300$ $\left.70814,500 \mathrm{cal}\left[12,975-12,410{ }^{14} \mathrm{C}\right] \mathrm{BP}\right)$ to the west and dominance of eastern glacial 709 meltwater inputs to the Ontario basin. 
Glacial meltwater originating both from glacial Lake Algonquin and directly from

711 the LIS contributed to glacial Lake Iroquois, which was established in the Ontario basin

712 when LIS retreat blocked the Ontario basin's outlet to the St. Lawrence River $(14,000-$

$\left.71313,260 \mathrm{cal}\left[12,150-11,360{ }^{14} \mathrm{C}\right] \mathrm{BP}\right)$. Generally lower $\delta^{18} \mathrm{O}_{\text {lakewater }}(-18.1 \pm 0.7 \%$ o $)$ in the

714 eastern portion of glacial Lake Iroquois indicates contributions of meltwater from the

715 LIS. More variable $\delta^{18} \mathrm{O}_{\text {lakewater }}(-16.8 \pm 2.0 \%)$ in the central portion of glacial Lake

716 Iroquois suggests fluctuations in the relative inflows from the east-central outlet of glacial

717 Lake Algonquin, western sources and direct LIS runoff.

718 Retreat of the LIS from the St. Lawrence valley shortly after 13,260 cal [11,360

$\left.719{ }^{14} \mathrm{C}\right] \mathrm{BP}$ led to eastward drainage of glacial Lake Iroquois and successive lowstand

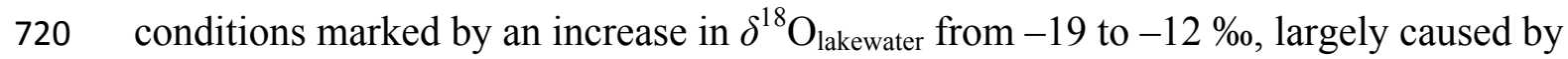

721 the loss of glacial meltwater input. A decrease in $\delta^{18} \mathrm{O}_{\text {lakewater }}$ from $\sim-12$ to $-14 \%$

722 shortly thereafter, about the time of the YD, marked entry of a final pulse of glacial

723 meltwater into the Ontario basin, likely from glacial Lake Algonquin. Meltwater entering

724 the Ontario basin beginning at $\sim 13,000$ cal $\left[11,110{ }^{14} \mathrm{C}\right]$ BP may have had brief

725 connectivity to the Atlantic Ocean, but after $\left.12,900 \mathrm{cal}\left[11,020{ }^{14} \mathrm{C}\right] \mathrm{BP}\right)$, there is no

726 compelling evidence that this glacial meltwater reached the Atlantic Ocean. The

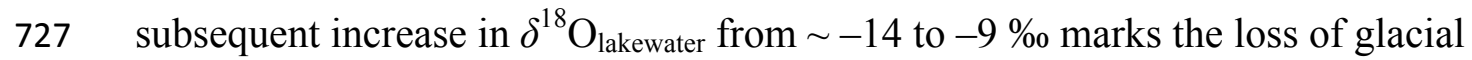

728 meltwater input and hydrologic closure of Lake Ontario. This change in conditions and

729 lower lake levels in particular were marked by appearance of Pisidium sp. clams and the

730 ostracode species F. caudata. Evaporation under cold and dry conditions during this time

731 is indicated by $\delta^{18} \mathrm{O}_{\text {lakewater }}$ as high as $-6 \%$. By the time of the Nipissing phase, 
732 conditions in the Ontario basin captured by the $\delta^{18} \mathrm{O}_{\text {lakewater }}$ signal were not significantly

733 different from the present time $(-6.6 \%)$.

734

735 Acknowledgements

736 We thank Allan Crowe (Canada Centre for Inland Waters, Environment Canada) for

737 facilitating core sampling, the Captain and crew of the CCGS Limnos for core collection,

738 and the staff of the Laboratory for Stable Isotope Science (LSIS) at the University of

739 Western Ontario for assistance with stable isotope analyses. We are grateful to John King

740 (Graduate School of Oceanography, University of Rhode Island) for core images,

741 Francine McCarthy (Brock University) for pollen extraction, and University of Arizona

742 (AMS) laboratory for radiocarbon dates. We especially thank Editor Dr. Claude Hillaire-

743 Marcel, Dr. Eric Carson and an anonymous reviewer for providing insightful feedback

744 that greatly improved this manuscript. Operating funds were provided by a Natural

745 Sciences and Engineering Research Council of Canada Discovery Grant (FJL) and an

746 Ontario Graduate Scholarship (RH). Infrastructure support was provided by the Canada

747 Foundation for Innovation and the Ontario Research Fund (FJL). The research was also

748 made possible in part through additional research time provided through the Canada

749 Research Chairs program. This is LSIS contribution \# 333.

750

751 References

752 Anderson, T.W., Lewis, C.F.M., 2012. A new water-level history for Lake Ontario basin:

753 evidence for a climate-driven early Holocene lowstand. Journal of Paleolimology

$754 \quad 47,513-530$. doi:10.1007/s10933-011-9551-8 
755 Broecker, W.S., Kennett, J.T., Flower, B.P., Teller, J.T., Trumbore, S., Bonani, G.,

756 Wolfli, W., 1989. Routing of meltwater from the Laurentide Ice Sheet during the

757 Younger Dryas cold episode. Nature 341, 318-320. doi:10.1038/341318a0

758 Bumstead, N.L., Longstaffe, F.J., Macdonald, R.A., 2009. The paleolimnology of Lake

759 Simcoe: oxygen-isotope compositions of ostracodes. $11^{\text {th }}$ International

760 Paleolimnology Symposium, Guadalajara, Mexico, December 15-18, 2009.

761 Carlson, A.E., Clark, P.U., Haley, B.A., Klinkhammer, G.P., Simmons, K., Brook, E.J.,

762 Meissner, K.J., 2007. Geochemical proxies of North American freshwater routing

763 during the Younger Dryas cold event. Proceedings of the National Academy of

764 Sciences 104, 6556-6561.

765 Carlson, A. E., Clark, P.U., 2012. Ice sheet sources of sea level rise and freshwater

766 discharge during the last deglaciation. Reviews of Geophysics 50, RG4007.

767 doi:10.1029/2011RG000371.

768 Carmichael, C.M., Mothersill, J.S., Morris W.A., 1990. Paleomagnetic and pollen

769 chronostratigraphic correlations of the late glacial and postglacial sediments in Lake

770 Ontario. Canadian Journal of Earth Sciences 27, 131-147. doi:10.1139/e90-011

771 Calkin, P.E., Feenstra, B.H., 1985. Evolution of the Erie-basin Great Lakes. In: Karrow,

772 P.F., Calkin, P.E., (Eds.), Quaternary Evolution of the Great Lakes. Geological

773 Association of Canada Special Paper 30, pp. 149-170.

774 Coakley, J.P., Karrow, P.F., 1994. Reconstruction of post-Iroquois shoreline evolution in

775 western Lake Ontario. Canadian Journal of Earth Sciences 31, 1618-1629. doi:

$776 \quad 10.1139 / \mathrm{e} 94-143$ 
777 Condron, A., Winsor, P., 2012. Meltwater routing and the Younger Dryas. Proceedings of

778 the National Academy of Sciences 109, 19928-19933. doi:

779 10.1073/pnas.1207381109

780 Coplen, T.B., 1996. New guidelines for reporting stable hydrogen, carbon, and oxygen isotope ratio data. Geochimica et Cosmochimica Acta 17, 3359-3360. doi: 10.1016/0016-7037(96)00263-3

783 Cronin, T.M., Rayburn, J.A., Guilbault, J.-P., Thunell, R., Franzi, D.A., 2012. Stable

doi:10.1016/j.quaint.2011.08.041

Decrouy, L., Vennemann, T.W., Ariztegui, D., 2011a. Controls on ostracod valve isotope evidence for glacial lake drainage through the St. Lawrence Estuary, eastern Canada, 13.1-12.9 ka. Quaternary International 260, 55-65. geochemistry, Part 1: Variations of environmental parameters in ostracod (micro-) habitats. Geochimica et Cosmochimica Acta 75, 7364-7379.

doi:10.1016/j.gca.2011.09.009

Decrouy, L., Vennemann, T.W., Ariztegui, D., 2011b. Controls on ostracod valve geochemistry: Part 2. Carbon and oxygen isotope compositions. Geochimica et Cosmochimica Acta 75, 7380-7399. doi:10.1016/j.gca.2011.09.008

Delorme, L.D., 1978. Distribution of freshwater ostracodes in Lake Erie. Journal of Great Lakes Research 4, 216-220.

Delorme, L.D., 1989. Methods in Quaternary ecology \#7. Freshwater ostracodes. Geoscience Canada 16, 85-90.

Donnelly, J.P, Driscoll, N.W., Uchupi, E., Keigwin, L.D., Schwab, W.C., Theiler, E.R., 799 Swift, S.A., 2005. Catastrophic meltwater discharge down the Hudson Valley: A 
potential trigger for the Intra-Allerød cold period. Geology 33, 89-92. doi:10.1130/G21043.1

Dyke, A.S., 2004. An outline of North American deglaciation with emphasis on central and northern Canada. In: Ehlers, J., Gibbard, P.L. (Eds.), Quaternary Glaciations — Extent and Chronology, part II. North America. Developments in Quaternary Science 2, pp. 373-424.

Edwards, T.W.D., Fritz, P., 1986. Assessing meteoric water composition and relative humidity from ${ }^{18} \mathrm{O}$ and ${ }^{2} \mathrm{H}$ in wood cellulose: paleoclimatic implications for southern Ontario. Applied Geochemistry 1, 715-723.

Edwards, T.W.D., McAndrews, J.H., 1989. Paleohydrology of a Canadian Shield lake inferred from ${ }^{18} \mathrm{O}$ in sediment cellulose. Canadian Journal of Earth Sciences 26, 1850-1859, doi: 10.1139/e89-158

Edwards, T.W.D., Wolfe, B.B., MacDonald, G.M., 1996. Influence of changing atmospheric circulation on precipitation $\delta^{18} \mathrm{O}$-temperature relations in Canada during the Holocene. Quaternary Research 46, 211-218. doi:10.1006/qres.1996.0061

Eschman, D.F., Karrow, P.F., 1985. Huron basin glacial lakes: a review. In: Karrow, P.F., Calkin, P.E., (Eds.), Quaternary Evolution of the Great Lakes. Geological Association of Canada Special Paper 30, pp. 79-93.

Fahl, K., Stein, R., 2012. Modern seasonal variability and deglacial/Holocene change of central Arctic Ocean sea-ice cover: new insights from biomarker proxy records. Earth and Planetary Science Letters 351-352, 123-133. doi:10.1016/j.eps1.2012.07.009 
823 Ferguson, G., Jasechko, S., 2015. The isotopic composition of the Laurentide Ice Sheet and fossil groundwater. Geophysical Research Letters 42, 4856-4861. doi: $10.1002 / 2015$ GL064106

826 Friedman, I., O’Neil, J. R., 1977. Compilation of stable isotope fractionation factors of geochemical interest. In: Fleischer, M. (Ed.) US Geological Survey Professional

Hillaire-Marcel, C., 1981. Paléo-océanographie isotopique des mers postglaciaires du Québec. Palaeogeography, Palaeoclimatology, Palaeoecology 35, 35-119. doi:10.1016/0031-0182(81)90094-8

Hladyniuk, R., 2014. Late Quaternary paleolimnology of Lake Ontario. The University of Western Ontario - Electronic Thesis and Dissertation Repository (Paper 2401).

Hladyniuk, R., Longstaffe, F.J., 2015. Paleoproductivity and organic matter sources in Late Quaternary Lake Ontario. Palaeogeography, Palaeoclimatology, Palaeoecology 435, 13-23. doi:10.1016/j.palaeo.2015.05.026

Hutchinson, D.R., Lewis, C.F.M., Hund, G.E., 1993. Regional stratigraphic framework of surficial sediments and bedrock beneath Lake Ontario. Géographie Physique Quaternaire 47, 337-335. doi:10.7202/032962ar

Levac, E., Lewis, C.F.M., Stretch, V., Duchesne, K., Neulieb, T., 2015. Evidence for meltwater drainage via the St. Lawrence River Valley in marine cores from the Laurentian Channel at the time of the Younger Dryas. Global and Planetary Change 130, 47-65. doi:10.1016/j.gloplacha.2015.04.002 
845 Leverington, D.W., Mann, J.D., Teller, J.T., 2000. Changes in the bathymetry and

846

847

848

849

850

851

852

853

854

855

856

857

858

859

860

861

862

863

864

865

866

867 volume of glacial Lake Agassiz between 11,000 and 9,300 ${ }^{14} \mathrm{C}$ yr BP. Quaternary

Research 54: 174-181. doi:10.1006/qres.2000.2157

Lewis, C.F.M., Moore, J.T.C., Rea, D.K., Dettman, D.L., Smith, A.M., Mayer, L.A., 1994. Lakes of the Huron Basin: their record of runoff from the Laurentide Ice

Sheet. Quaternary Science Reviews 13: 891-922. doi:10.1016/02773791(94)90008-6

Lewis, C.F.M., King, J.W., Blasco, S.M., Brooks, G.R., Coakley, J.P., Croley II, T.E., Dettman, D.L., Edwards, T.W.D., Heil Jr., C.W., Hubeny, J.B., Laird, K.R., McAndrews, J.H., McCarthy, F.M.G., Medioli, B.E., Moore Jr., T.C., Rea, D.K., Smith, A.J., 2008. Dry climate disconnected the Laurentian Great Lakes. EOS, Transactions American Geophysical Union 89, 541-542.

Lewis, C.F.M., Cameron, G.D.M., Anderson T.W., Heil Jr., C.W., Gareau, P.L., 2012. Lake levels in the Erie Basin of the Laurentian Great Lakes. Journal of Paleolimnology 47, 493-511. doi:10.1007/s10933-012-9578-5

Longstaffe, F.J., Ayalon, A., Bumstead, N.L., Crowe, A.S., Hladyniuk, R., Hornibrook, P.A., Hyodo, A., Macdonald, R.A., 2011. The oxygen-isotope evolution of the North American Great Lakes. Northeastern (46 ${ }^{\text {th }}$ Annual) and North-Central $\left(45^{\text {th }}\right.$ Annual) Joint Meeting of the Geological Society of America, Pittsburgh, Pennsylvania, USA, March 20-22, 2011, p. 57.

Macdonald, R.A., Longstaffe, F.L., 2008. The Late Quaternary oxygen-isotope composition of southern Lake Huron. Aquatic Ecosystem Health and Management 11, 137-143. doi:10.1080/14634980802097236 
868 McAndrews, J.H., 1994. Pollen diagrams for southern Ontario applied to archeology. In:

869 MacDonald, R.I. (Ed.) Great Lakes Archeology and Paleoecology: Exploring

870 Interdisciplinary Initiatives for the Nineties. Quaternary Sciences Institute,

871 University of Waterloo, Waterloo, pp. 179-195.

872 McFadden, M.A., Patterson, W.P., Mullins, H.T., Anderson, W.T., 2005. Multi-proxy

873 approach to long-and short-term Holocene climate-change: evidence from eastern

$874 \quad$ Lake Ontario. Journal of Paleolimnology 33, 371-391.

875 Moore Jr., T.C., Walker, J.G.C., Rea, D.K., Lewis, C.F.M., Shane, L.C.K., Smith, A.J.,

876 2000. The Younger Dryas interval and outflow from the Laurentide ice sheet.

877 Paleoceanography 15, 9-18. doi:10.1029/2006PA001340.

878 Muller, E.H., Prest, V.K., 1985. Glacial lakes in the Ontario basin. In: Karrow, P.F.,

879 Calkin, P.E., (Eds.), Quaternary Evolution of the Great Lakes. Geological

$880 \quad$ Association of Canada Special Paper 30, pp. 211-229.

881 Munsell Color. 2000. Munsell Soil Color Charts Year 2000 Revised Washable Edition.

882 GretagMacbeth, New Windsor, NY.

883 Murton, J.B., Bateman, M.D., Dallimore, S.R., Teller, J.T., Yang, Z., 2010. Identification

884 of Younger Dryas outburst flood path from Lake Agassiz to the Arctic Ocean.

$885 \quad$ Nature $464,740-743$. doi:10.1038/nature08954

886 National Oceanic and Atmospheric Administration Digital Elevation Model (DEM)

887 Discovery Portal website (2015). Retrieved June 15, 2015 from

888 http://ngdc.noaa.gov/mgg/dem/ 
889 Occhietti, S., 2007. The Saint-Narcisse morainic complex and early Younger Dryas

890 events on the southeastern margin of the Laurentide Ice Sheet. Géographie Physique Quaternaire 61, 89-117. doi:10.7202/038987ar

892

893

894

895

896

897

898

899

900

901

902

903

904

905

906

907

908

909

910

911

Occhietti, S., Parent, M., Shilts, W.W., Dionne, J.-C., Govare, E., Harmand, D., 2001. Late Wisconsinan glacial dynamics, deglaciation and marine invasion in southern Québec. In: Weddle, T.K., Retelle, M.J. (Eds.), Deglacial History and Relative Sealevel Changes, 351. Geological Society of America, Northern New England and Adjacent Canada, Boulder, Colorado, pp. 245-272. Special Paper.

Occhietti, S., Richard, P.J.H., 2003. Effet réservoir sur les âges ${ }^{14} \mathrm{C}$ de la Mer de Champlain à la transition Pléistocène-Holocène: révision de la chronologie de la déglaciation au Québec méridional. Géographie Physique Quaternaire 57, 115138. doi:10.7202/011308ar

Parent, M., Occhietti, S., 1988. Late Wisconsinan deglaciation and Champlain Sea invasion in the St. Lawrence Valley, Quebec. Géographie Physique et Quaternaire 42, 215-246. doi:10.7202/032734ar

Pippert, R.G., Brown, G.R., Morris, W.A., 1996. Palaeomagnetic chronostratigraphy of Holocene sediments, Niagara basin, Lake Ontario, Canada. Journal of Quaternary Science 11, 217-231. doi:10.1002/(SICI)1099-1417(199605/06)

Rayburn, J.A., Knuepfer, P.L.K., Franzi, D.A., 2005. A series of large, Late Wisconsinan meltwater floods through the Champlain and Hudson valleys, New York, USA, Quaternary Science Reviews 24, 2410-2419. doi:10.1016/j.quascirev.2005.02.010.

Rayburn, J.A., Franzi, D.A., Knuepfer, P.L.K., 2007. Evidence from the Lake Champlain Valley for a later onset of the Champlain Sea and implications for late glacial 
meltwater routing to North Atlantic. Palaeogeography, Palaeoclimatology, Palaeoecology 246, 62-74. doi:10.1016/j.palaeo.2006.10.027

Rayburn, J.A., Cronin, T.M., Franzi, D.A., Knuepfer, P.L.K., Willard, D.A., 2011. Timing and duration of North American glacial lake discharges and the Younger Dryas climate reversal. Quaternary Research 75, 541-551. doi:10.1016/j.yqres.2011.02.004

Reimer, P.J., Baillie, M.G.L., Bard, E., Bayliss, A., Beck, J.W., Blackwell, P.G., Bronk Ramsey, C., Buck, C.E., Burr, G.S., Edwards, R.L., Friedrich, M., Grootes, P.M., Guilderson, T.P., Hajdas, I., Heaton, T.J., Hogg, A.G., Hughen, K.A., Kaiser, K.F., Kromer, B., McCormac, F.G., Manning, S.W., Reimer, R.W., Richards, D.A., Southon, J.R., Talamo, S., Turney, C.S.M., van der Plicht, J., Weyhenmeyer, C.E., 2009. IntCa109 and Marine09 radiocarbon age calibration Curves, 0-50,000 Years cal BP. Radiocarbon 51, 1111-1150.

Richard, P.J.H., Occhietti, S., 2005. ${ }^{14} \mathrm{C}$ chronology for ice retreat and inception of Champlain Sea in the St. Lawrence Lowlands, Canada. Quaternary Research 63, 353-358. doi:10.1016/j.yqres.2005.02.003

Silliman, J.E., Meyers, P.A., Bourbonniere, R.A., 1996. Record of postglacial organic matter delivery and burial in sediments of Lake Ontario. Organic Geochemistry 24 (4), 463-472. doi:10.1016/0146-6380(96)00041-1

Teller, J.T., 1985. Glacial Lake Agassiz and its influence on the Great Lakes. In: Karrow, P.F., Calkin, P.E., (Eds.), Quaternary Evolution of the Great Lakes. Geological Association of Canada Special Paper 30, pp. 1-16. 
934 Teller, J.T., 1988. Lake Agassiz and its contribution to flow through the Ottawa-St.

935 Lawrence system. In: Gadd, N.R. (Ed.), The Late Quaternary Development of the

936 Champlain Sea Basin, 35. Geological Association of Canada, pp. 281-289.

$937 \quad$ Special Paper.

938 Teller, J.T., Boyd, M., Yang, Z., Kor, P.S.G., Fard, A.M., 2005. Alternative routing of

939 Lake Agassiz during the Younger Dryas: new dates, paleotopography and a re-

940 evaluation. Quaternary Science Reviews 24, 1890-1905.

941 doi:10.1016/j.quascirev.2005.01.008

942 Thompson, T.A, Lepper, K., Endres. A.L., Johnston, J.W., Baedke, S.J., Argyilan, E.P.,

943 Booth, R.K., Wilcox, D.A., 2011. Mid Holocene lake level and shoreline behavior

944 during the Nipissing phase of the upper Great Lakes at Alpena, Michigan, USA.

$945 \quad$ Journal of Great Lakes Research, 37 (2011) 567-576.

$946 \quad$ doi:10.1016/j.jglr.2011.05.012

947 von Grafenstein, U., Erlernkeuser, H., Trimborn, P., 1999. Oxygen and carbon isotopes in

948 modern fresh-water ostracod valves: assessing vital offsets and autecological effects

949 of interest for palaeoclimate studies. Palaeogeography, Palaeoclimatology,

950 Palaeoecology 148, 133-152. doi:10.1016/S0031-0182(98)00180-1

951 Voytek, E.B., Colman, S.M., Wattrus, N.J., Gary, J.L., Lewis, C.F.M., 2012. Thunder

952 Bay, Ontario, was not a pathway for catastrophic floods from Glacial Lake Agassiz.

953 Quaternary International 260, 98-105. doi:10.1016/j.quaint.2011.10.040 
Hladyniuk and Longstaffe- Oxygen-isotope variations in post-glacial Lake Ontario Figure captions

Figure 1. Digital Elevation Models (DEM) of the Great Lakes basin. Important inlets, outlets and other locations are labeled. (a) Great Lakes basin and position of the Laurentide Ice Sheet at $\sim 13,260 \mathrm{cal}\left[11,350{ }^{14} \mathrm{C}\right] \mathrm{BP}$ (Dyke, 2004). Glacial Lake Agassiz (Lockhart phase) drained through the southern outlet (SO) (Leverington et al., 2000). Later in the Lockhart phase and during the Moorhead phase, glacial Lake Agassiz is postulated to have switched from a southern outlet (SO) to an eastern outlet (EO) flowing to glacial Lake Algonquin (Teller, 1985). Early glacial Lake Algonquin's outlet was at Port Huron (PH), which allowed water to enter glacial Lake Iroquois through Niagara Falls (NF) from the Erie basin. Later, during the KirkfieldAlgonquin phase (of glacial Lake Algonquin), water reached glacial Lake Iroquois through the Fenelon Falls (FF) outlet (Eschman and Karrow, 1985; Muller and Prest, 1985). Outflow from glacial Lake Iroquois travelled through the Mohawk River valley, eventually reaching the Atlantic Ocean (Donnelly et al., 2005). (b) Following the draining of glacial Lake Iroquois around 12,900 cal $\left[11,900{ }^{14} \mathrm{C}\right] \mathrm{BP}$ early Lake Ontario became confluent with the neighbouring Champlain Sea that inundated the St. Lawrence valley (Anderson and Lewis, 2012). (c) Present configuration of the Great Lakes. All figures modified from the National Oceanic and Atmospheric Administration data center website (http://ngdc.noaa.gov/mgg/dem/).

Figure 2. DEM of Lake Ontario region showing piston core locations: Core $1334\left(43^{\circ} 24^{\prime} 23^{\prime \prime} \mathrm{N}\right.$ and $79^{\circ} 00^{\prime} 05^{\prime \prime} \mathrm{W}$; water depth, $110.3 \mathrm{~m}$; core length, $\left.17.00 \mathrm{~m}\right)$, Core $1335\left(43^{\circ} 33^{\prime} 19^{\prime \prime} \mathrm{N}\right.$ and $78^{\circ} 09^{\prime} 01^{\prime \prime} \mathrm{W}$; water depth, $192 \mathrm{~m}$; core length, $\left.18.20 \mathrm{~m}\right)$, Core $1336\left(43^{\circ} 30^{\prime} 28^{\prime \prime} \mathrm{N}\right.$ and $76^{\circ}$ 
53' 07' W; water depth, $221.5 \mathrm{~m}$; core length, $18.41 \mathrm{~m}$ ). Major inlets and outlets during Lake Ontario's history are labelled. Figure modified from the National Oceanic and Atmospheric Administration data center website (http://ngdc.noaa.gov/mgg/dem/).

Figure 3. Generalized lithology of the Lake Ontario sediments in Cores 1334, 1335 and 1336. Locations of radiocarbon-dated material are denoted by stars. Sediment colour codes follow Munsell Color (2000).

Figure 4. Depth versus: median grain size; bulk sediment mineralogy (triangles, feldspars; squares, clays; stars, carbonates; filled circles, quartz); ostracode abundances, valves per gram sediment (v/g); and $\delta^{18} \mathrm{O}_{\text {lakewater }}$ inferred from ostracode valves (open circles, C. subtriangulata; stars, F. caudata) and clam shells (filled triangles) for Core 1334 (Niagara basin), Core 1335 (Mississauga basin) and Core 1336 (Rochester basin). Lithological unit boundaries (see text) are shown by continuous solid (grey) horizontal lines. Important lithological markers (see text) within units are denoted by dashed (grey) horizontal lines. Braces demarcate biostratigraphic zonations as described in the text.

Figure 5. Lake elevation and $\delta^{18} \mathrm{O}_{\text {lakewater }}$ versus calibrated age in the main Ontario basin. The thick black line indicates the inferred lake level presented by Anderson and Lewis (2012). Major lake phases are noted at the top of the diagram. Values of $\delta^{18} \mathrm{O}_{\text {lakewater }}$ inferred from $C$. subtriangulata (triangles) and Pisidium sp. clams (circles) are shown for Core 1335, and more generally by the colour gradient from low (blue) to high (orange). 

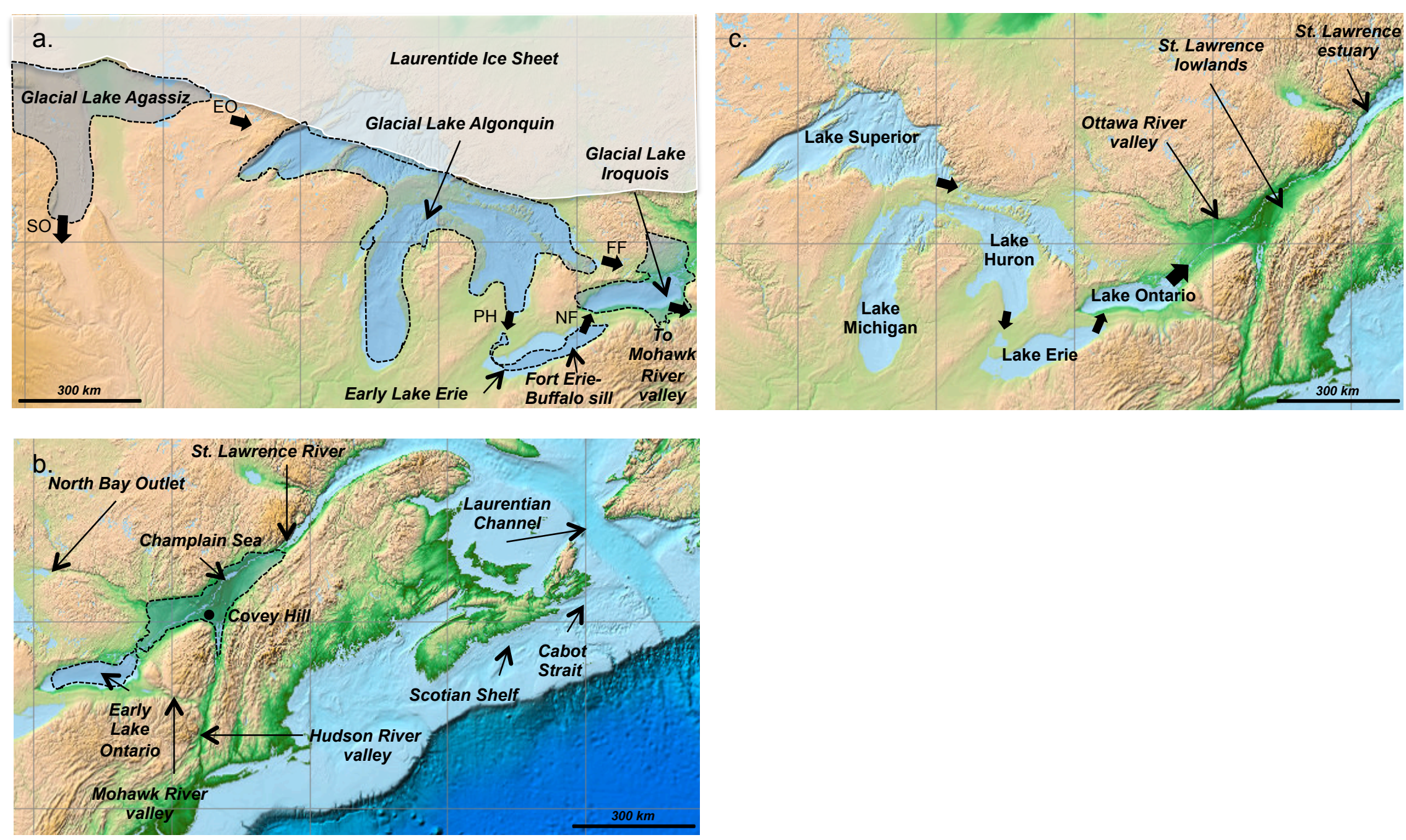

Figure 1.

These figures are a 1-column fitting images (stacked in three). Color only for web version. 


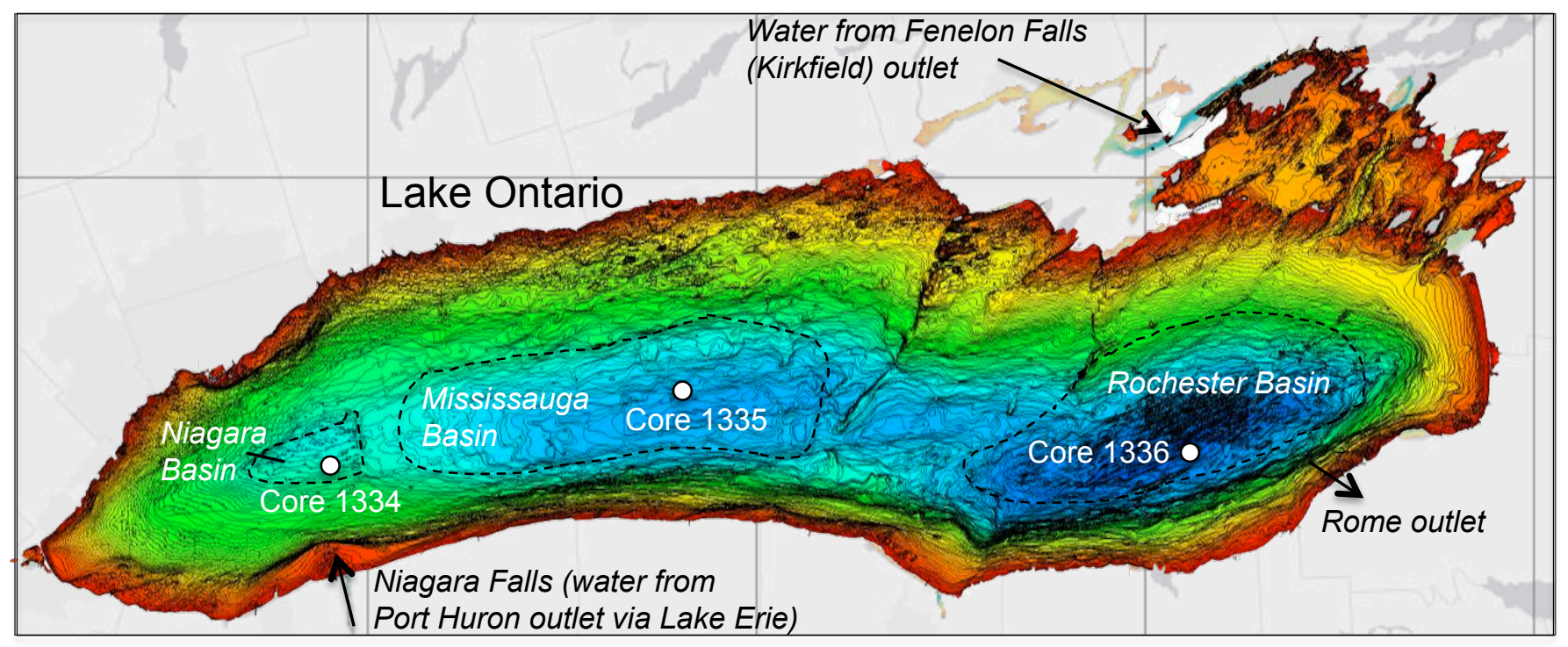

Figure 2.

This figure is a 2-column fitting image. Color only for web version. 


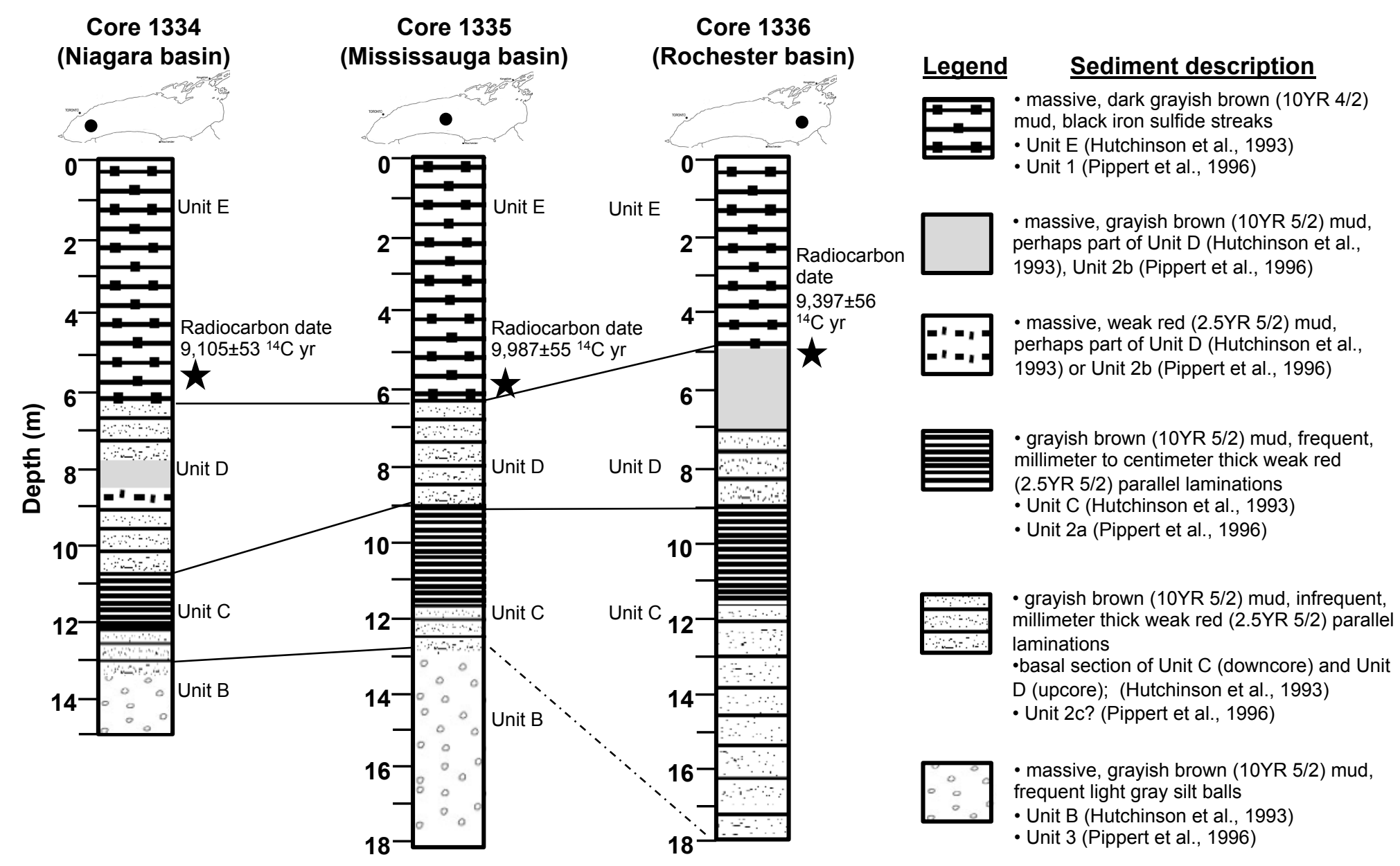

Figure 3.

This figure is a 2-column fitting image. 
Grain size

(diameter at 50\%, $\mu \mathrm{m}$ )

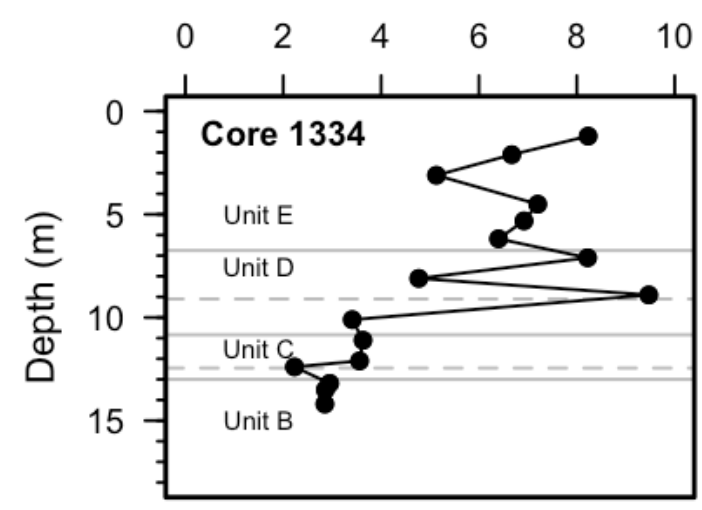

$\begin{array}{llllll}0 & 2 & 4 & 6 & 8 & 10\end{array}$
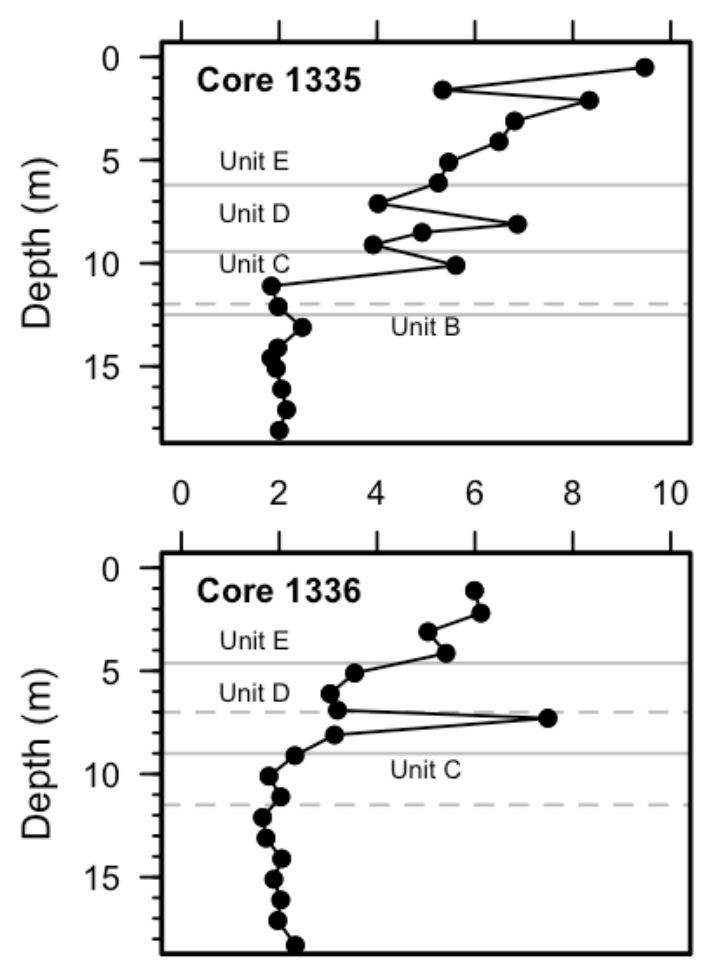

Mineralogy

(relative abundance, \%)
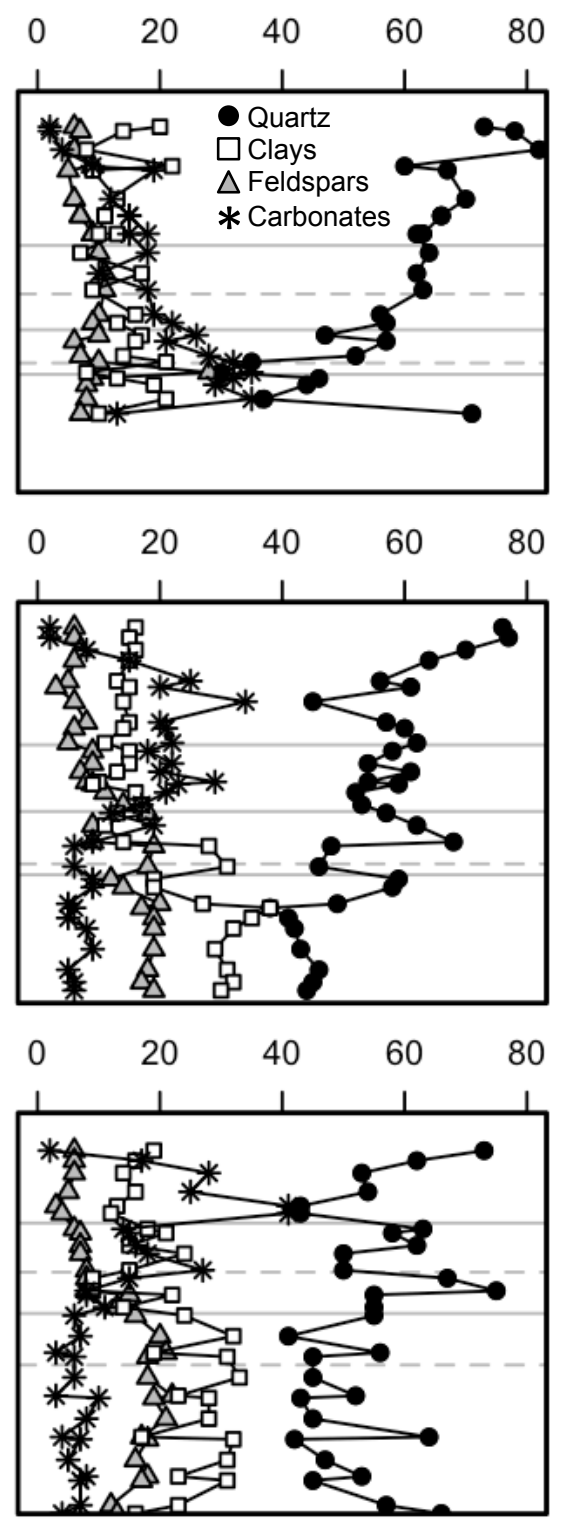

Ostracode abundance

(valves/gram sediment)
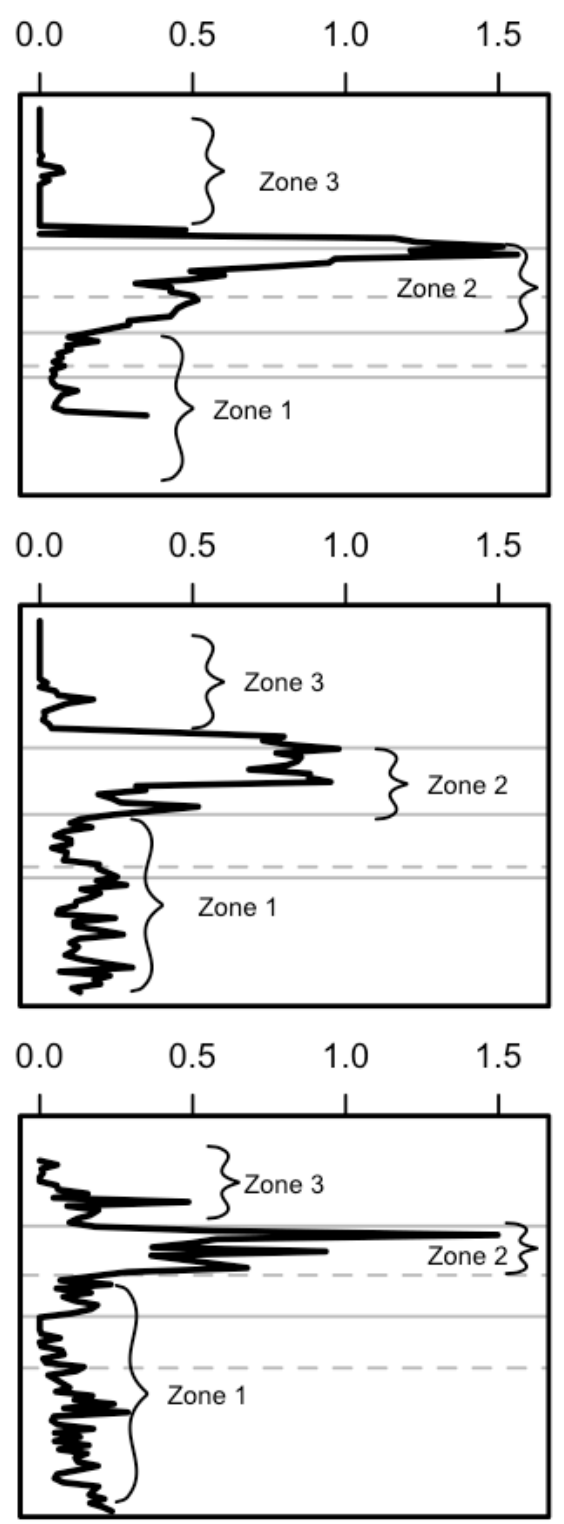

Lakewater $\delta^{18} \mathrm{O}$

(VSMOW, \%o)
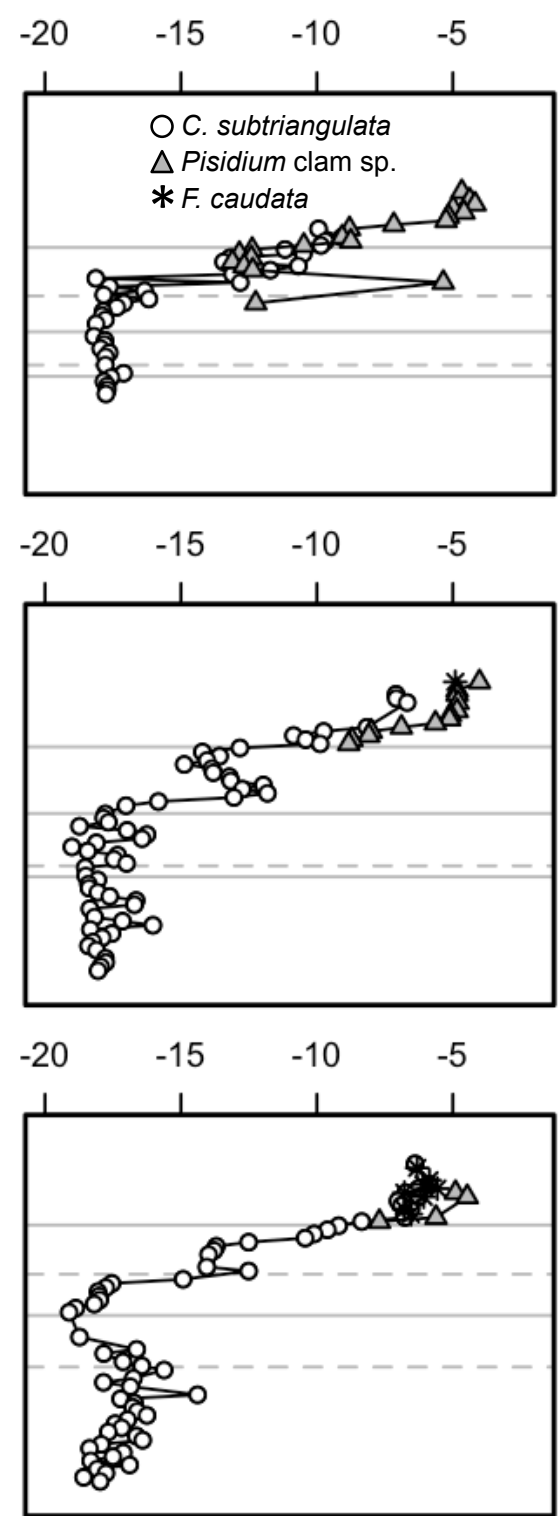

Figure 4. This figure is a 2-column fitting image. 


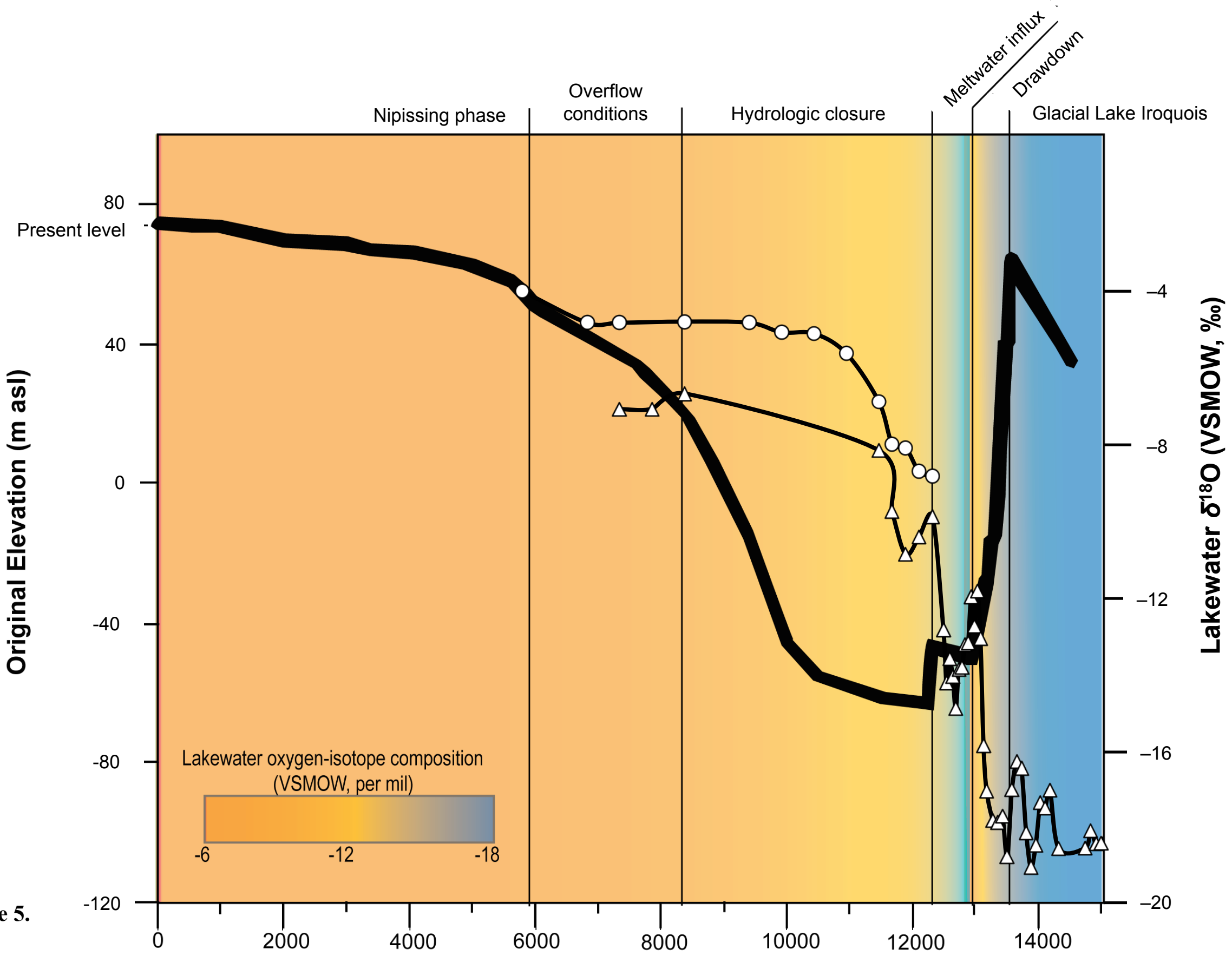

This figure is a 2-column fitting image. Color for web version only.

Calibrated age (years BP) 